\title{
Article
}

\section{Quality Evaluation of Winery By-Products from Ionian Islands Grape Varieties in the Concept of Circular Bioeconomy}

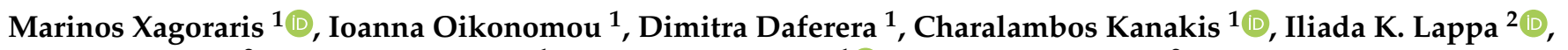 \\ Charilaos Giotis ${ }^{2}$, Christos S. Pappas ${ }^{1}$, Petros A. Tarantilis ${ }^{1}$ (i) and Efstathia Skotti ${ }^{2, *}$ \\ 1 Laboratory of Chemistry, Department of Food Science and Human Nutrition, Agricultural University of \\ Athens, 75 Iera Odos, 11855 Athens, Greece; mxagor@aua.gr (M.X.); oikon.gianna@gmail.com (I.O.); \\ daferera@aua.gr (D.D.); chkanakis@aua.gr (C.K.); chrispap@aua.gr (C.S.P.); ptara@aua.gr (P.A.T.) \\ 2 Department of Food Science and Technology, Ionian University, Terma Leoforou Vergoti, \\ 28100 Argostoli, Cephalonia, Greece; lappalida@gmail.com (I.K.L.); hgiotis@ionio.gr (C.G.) \\ * Correspondence: efskotti@ionio.gr; Tel.: +30-267-1029-055 or +30-694-3933-574
}

check for updates

Citation: Xagoraris, M.; Oikonomou, I.; Daferera, D.; Kanakis, C.; Lappa,

I.K.; Giotis, C.; Pappas, C.S.;

Tarantilis, P.A.; Skotti, E. Quality Evaluation of Winery By-Products from Ionian Islands Grape Varieties in the Concept of Circular Bioeconomy. Sustainability 2021, 13, 5454. https:// doi.org/10.3390/su13105454

Academic Editor: Antonia Terpou

Received: 27 March 2021

Accepted: 12 May 2021

Published: 13 May 2021

Publisher's Note: MDPI stays neutral with regard to jurisdictional claims in published maps and institutional affiliations.

Copyright: (C) 2021 by the authors Licensee MDPI, Basel, Switzerland. This article is an open access article distributed under the terms and conditions of the Creative Commons Attribution (CC BY) license (https:/ / creativecommons.org/licenses/by/ $4.0 /)$.

\begin{abstract}
The aim of this work was the study and evaluation of winery by-products in the framework of the circular bioeconomy. Grape seeds and grape skins from Greek Ionian Islands varieties were analyzed in an attempt to provide the appropriate basis for model development of their sustainable exploitation at a local or regional level. The by-products were collected directly from the wineries immediately after the vinification process and were analyzed by chromatographic and spectroscopic techniques. In addition, annual production and yields were estimated. Grape seed oil quality was evaluated based on fatty acid methyl ester (FAME) composition. The grape skins' phenolic fraction was extracted by an eco-friendly, nontoxic water-glycerol solvent system and was detected qualitatively. In addition, total phenolic content (TPC) and antioxidant activity (ABTS, DPPH) were measured. Based on estimated yields, our results demonstrate that winery by-products have the potential to promote the cyclical bioeconomy in a modern economic growth model that will reduce by-products and environmental costs as they can be reused as whole material in foods, dietary supplements, cosmetic ingredients, food colorants, and preservatives.
\end{abstract}

Keywords: grape skins; grape seed oil; fatty acid methyl esters; total phenolic content; antioxidant activity; green extraction; circular bioeconomy

\section{Introduction}

Grapes are one of the world's largest fruit crops, with over 75 million tons grown annually, primarily as Vitis vinifera L. for wine production. According to Food and Agriculture Organization (FAO) statistics, wine production is substantial for the Greek economy, ranking as the country's second most profitable industry after olives in 2015 and 2016. [1]. Approximately 35.9 million tons of industry by-products arise from wine, while the rest arise from grape juice processing [2]. The Ionian Islands produced 1179.25 tons of wine grapes in 2017, according to the Ministry of Rural Development and Food, generating 175.12 tons of grape pomace [3]. All these by-products could acquire greater potential value if they are valorized properly.

The wine industry generates a significant amount of solid waste, which is primarily disposed of in the environment, causing economic and environmental problems $[4,5]$. Winery by-product wastes are produced continuously throughout the year and may be hazardous to the environment [6]. By-products are typically characterized by high levels of chemical oxygen demand (COD) and biodegradability [7]. Specifically, grape pomace consists mainly of grape seeds and skins and they remain after pressing and the fermentation during vinification processes.

Grape seeds are a valuable source of oily constituents like sterols, triglycerides, and fatty acids. Polyunsaturated and monounsaturated fatty acids (PUFAs and MUFAs) are 
abundant in grape seed oils, with PUFAs accounting for the majority of fatty acids. The yield of oil can range from 5.85 to 22.4 percent $(w / w)$, and it is dependent on the cultivar, variety, and year-to-year variations in extraction methods [8-10]. Grape skins are characterized by high-phenolic contents. The phenolic composition of grapes varies depending on grape variety and vinification conditions. The major phenolic compounds are anthocyanins, catechins, flavonol glycosides, phenolic acids, and stilbenes [11]. These compounds are responsible for some of the most essential wine characteristics while also acting as antioxidants. [12]. Many studies have evaluated the methods for the valorization of winery by-products. Antioxidant and health-promoting practices were the subject of these studies [4]. Phenolic compounds react to the free radicals and neutralize them with beneficial anti-inflammatory, cardioprotective, and anticarcinogenic effects [13]. The extraction of phenolic compounds from by-products can be done with many organic solvents such as methanol, ethanol, acetone, and ethyl acetate [12].

In general, islands are sensitive systems compared to the mainland. This is due to a variety of factors such as their small size, peculiar environment, unique climate, and relative isolation from the mainland. The small size, in terms of area and population, implies a limited variety and quantity of natural resources as well as fewer opportunities for large-scale productive activities. Furthermore, the distance from the urban centers combined with the traffic difficulties caused by the sea has a substantial impact on the degree of isolation. As a result of these characteristics, vulnerable environments with unpredictable environmental factors and minimal development capacity have emerged. A circular economy approach could contribute positively to the solution of the insularity problem. Materials and products must be reused, repaired, renewed, and recycled as part of the transition to a cyclical bioeconomy. Materials which were considered "by-products" can be turned into raw materials. Strengthening collaboration across the supply chain will help eliminate costs, waste, and environmental impact. Developments in environmental innovation ensure new products, processes, technologies, and organizational structure.

Valorization of a by-products' biomass for the recovery of phytochemicals should include processes that generate far less or even zero further by-products. Otherwise, no concept of "green" or "sustainable" could be substantiated. As a result, research should focus on the discovery and design of extraction processes that allow for the use of alternative solvents and sustainable natural resources while still ensuring a healthy and high-quality extract/product. [14]. Glycerol is a bio-liquid considered a by-product of the biodiesel industry and simultaneously has not been used widely for extraction purposes. In addition, it constitutes a green and well-established sustainable solvent $[15,16]$. Utilization of grape pomace as a whole product or combination with green solvents to extract bioactive compounds can be used in the food and cosmetic industry resulting in high added-value end products [17-19].

The aim of this research was to find a cost-effective solution for managing winery by-products while also supporting the circular bioeconomy. A quality analysis of grape pomace was conducted for this reason. Nontoxic, environmentally friendly solvents were used to extract the extracts, and the fractions were tested for antioxidant activity. For this purpose, traditional grape varieties of the Ionian Islands were selected. Finally, it should be highlighted that analyses were based on by-products just as they were taken from the wineries to provide a realistic view and the promotion of the cyclical bioeconomy. This research will also serve as a valuable contribution to a deeper investigation of the understudied topic of sustainable waste management of agricultural by-products in the Ionian Islands.

\section{Materials and Methods}

\subsection{Chemicals}

All the solvents used were extra purity ( $>99.5 \%)$ including water, glycerol and nhexane, cyclohexane, and methanol. Phenolic standards with a purity of $98-99 \%$ (cinnamic acid, gallic acid, caftaric acid, catechin and epicatechin, epicatechin gallate, rutin, 
quercetin, kaempferol-3-glucoside, p-coumaric acid, and isorharmentin-3-glucoside) were purchased from Aldrich (Steinheim, Germany) and used for identification in MS. FolinCiocalteu reagent was used for TPC measurement, as well as caffeic acid. 2,2-diphenyl-1picrylhydrazyl (DPPH) and 2,2'-azino-bis-(3-ethylbenzothiazoline-6-sulphonic acid) (ABTS), which were used for the free radicals preparation tests, as well as Trolox.

\subsection{Plant Material}

Winery by-products were provided by Gentillini Winery and Vineyards, the Robola Cooperative of Cephalonia, Ktima Grampsa, Ktima Theotoki, and Robotis wineries. Thirtysix samples were analyzed and some of them came from the PDO Robola in Cephalonia. The rest of them were varieties from Pavlos, Avgoustiatis, Robola, Goustolidi, Savvatiano, Cabernet Sauvignon, Kakotrygis, Sauvignon Blanc, Tsaousi, Mavrodaphne, Vardea, and Vertzami.

\subsection{Moisture Removal}

The initial moisture of crude grape pomace was estimated and expressed in $\%(w / w)$. The average moisture was estimated at $73 \%$. The drying process of samples was then carried out in dark on large non-absorbent surfaces at $35^{\circ} \mathrm{C}$ assisted by airflow until a final moisture content of $13 \%$ was achieved. The duration of the drying process was two days on average and followed by the separation of grape seeds from the skins using a series of sieves. Ratio of skins to seeds for every sample were also specified. Seeds and skins of each sample were sealed in polypropylene bags and stored at $-20{ }^{\circ} \mathrm{C}$ until their usage.

\subsection{Oil Extraction from Grape Seeds}

Grape seeds were powdered with a mixer (Philips HR 2074, N.V., Amsterdam, The Netherlands) for $20 \mathrm{~s}$. The crushed grape seed powder was continuously extracted with n-hexane in a soxhlet apparatus at $70{ }^{\circ} \mathrm{C}$ for $6 \mathrm{~h}$. The analogy of crushed seeds to $\mathrm{n}$-hexane was 1 to $10(w / v)$. Then, the n-hexane fraction was evaporated to dryness under reduced pressure at $35^{\circ} \mathrm{C}$ and residuals removed under nitrogen flow.

\subsection{Phenolic Extraction from Grape Skins}

The extraction of the phenolic compounds was performed using the solid-liquid extraction technique. Before extraction, grape skins were powdered with a mixer (Philips HR 2074, N.V., Amsterdam, The Netherlands) for 2 min with $15 \mathrm{~s}$ rest periods to avoid overheating. A defatting process was performed using 1:10 (w/v) n-hexane [12]. Then, defatted samples were extracted with a solvent mixture of water:glycerol $(80: 20 \mathrm{v} / \mathrm{v})$ at $600 \mathrm{rpm}$ for $60 \mathrm{~min}$ at room temperature $\left(25^{\circ} \mathrm{C}\right)$. All processes were done in triplicate and fractions were filtered through a $0.45 \mu \mathrm{m}$ filter and stored at $-20^{\circ} \mathrm{C}$ until further analysis.

\subsection{Determination of Total Phenolic Content}

TPC was estimated using the Folin-Ciocalteu reagent [20]. In the case of grape seed oil, $0.1 \mathrm{~mL}$ oil was diluted with deionized water to $5 \mathrm{~mL}$ in a $10 \mathrm{~mL}$ volumetric flask and the addition of $0.5 \mathrm{~mL}$ Folin-Ciocalteu reagent. After $3 \mathrm{~min}, 1 \mathrm{~mL}$ of saturated $\left(\mathrm{Na}_{2} \mathrm{CO}_{3}\right.$ $20 \% \mathrm{w} / \mathrm{v}$ ) solution was added. The content was mixed and diluted to volume with water and after $1 \mathrm{~h}$ measured at $765 \mathrm{~nm}$.

In the case of the grape skin extract, in well plated, $1.5 \mathrm{~mL}$ of deionized water, $25 \mu \mathrm{L}$ of the sample, and $125 \mu \mathrm{L}$ of Folin-Ciocalteu reagent were added and stirred well. At the end of $3 \mathrm{~min}$ we added $375 \mu \mathrm{L}$ of sodium carbonate solution and $475 \mu \mathrm{L}$ of deionized water. After $2 \mathrm{~h}$ it was measured at $765 \mathrm{~nm}$.

The TPC concentration $\left(\mathrm{C}_{\mathrm{TPC}}\right)$ was calculated and expressed as $\mathrm{mg}$ gallic acid equivalents per $\mathrm{mL}$ extract $\left(\mathrm{mg} \mathrm{GAE} \mathrm{mL}^{-1}\right)\left(\mathrm{y}=0.0012 \mathrm{x}+0.012 ; \mathrm{R}^{2}=0.9967\right.$; Figure $\left.\mathrm{S} 1\right)$. TPC yield 
$\left(Y_{T P C}\right)$ was calculated as mg gallic acid equivalents per $\mathrm{g}$ of dry weight (mg GAE g $\left.{ }^{-1}\right)$, using the following equation:

$$
Y_{T P C}\left(\frac{\text { mg gallic acid }}{\text { g dry weight }}\right)=C_{T P C} \times \frac{V}{m}
$$

where $(V)$ is the volume of the extraction and $(m)$ the dry weight of plant material $(\mathrm{g})$.

\subsection{Antioxidant Activity of Grape Seed Oils and Grape Skin Extracts}

Antioxidant activity was estimated using DPPH and ABTS assays and $\mathrm{A}_{\mathrm{AR}}$ was also calculated [21-25]. Grape seed oil was diluted in ethyl acetate (1:10) and $1 \mathrm{~mL}$ of the solution was added to $4 \mathrm{~mL}$ of DPPH solution $(0.08 \mathrm{mM})$. Instead of oil, the control was made with ethyl acetate. After $30 \mathrm{~min}$ in the dark, the absorbance was measured at $515 \mathrm{~nm}$. In the case of grape skin extract, $3 \mathrm{~mL}$ of DPPH solution were added to $30 \mu \mathrm{L}$ of each sample. The solutions were vortexed and kept at room temperature in the dark for $30 \mathrm{~min}$. Absorbance was measured in $515 \mathrm{~nm}$ as well. $A_{A R}$ was calculated as described above [24] and is shown in Equation (3).

The ABTS was prepared by the reaction of $25 \mathrm{~mL}$ of ABTS solution $(7 \mathrm{mM})$ with $440 \mu \mathrm{L}$ of potassium persulfate $(140 \mathrm{mM})$. The solution was left at room temperature for 16-18 $\mathrm{h}$. The solution was then diluted with ethanol to obtain an absorbance of $0.7 \pm 0.2$ at $734 \mathrm{~nm}$. A total of $100 \mu \mathrm{L}$ of each grape seed oil was mixed with $2 \mathrm{~mL}$ of ABTS, and the absorbance was measured after $6 \mathrm{~min}$ at $734 \mathrm{~nm}$. Additionally, $30 \mu \mathrm{L}$ of each grape skin extract was mixed with $3 \mathrm{~mL}$ of ABTS, and the absorbance was measured after $6 \mathrm{~min}$ at $734 \mathrm{~nm}$ as well.

All measurements were expressed as $\mathrm{mg}$ Trolox equivalents $\mathrm{g}^{-1}$ dry weight (DPPH: $y=11.554 x-2.3777 ; R^{2}=0.9947 ;$ Figure S2) (ABTS: $y=18.248+1.4155 ; R^{2}=0.9907 ;$ Figure S3). Furthermore, $\mathrm{A}_{\mathrm{AR}}$ was calculated as previously described and is shown in Equation (3). $\mathrm{A}_{\mathrm{AR}}$ is expressed as $\mu \mathrm{mol}$ of $\mathrm{DPPH} \mathrm{g}{ }^{-1}$ of dry weight. The percentage of inhibition was calculated according to the following formula:

$$
\begin{gathered}
D P P H(\text { Inhibition } \%)=\left(\frac{A_{\text {blank }}-A_{\text {sample }}}{A_{\text {blank }}}\right) \times 100 \\
A_{A R}(\mu m o l D P P H / g d w)=\frac{C_{D P P H}}{C_{T P C}} \times\left(1-\frac{A_{515(f)}}{A_{515(i)}}\right) \times Y_{T P C}
\end{gathered}
$$

where $C_{D P P H}$ is the initial molar concentration of DPPH $\left(\mu \mathrm{mol} \mathrm{L}^{-1}\right), A_{515(f)}$ is the sample's absorbance, and $A_{515(i)}$ is the absorbance of the blank sample.

\subsection{Analysis of FAMEs in Grape Seed Oils by GC-MS}

The analysis of FAMEs was performed using a Trace Ultra gas chromatograph (GC) (Thermo Scientific Inc., Waltham, MA, USA), coupled to a mass spectrometer (MS) (DSQII, Thermo Scientific Inc., Waltham, MA, USA). The column used was a TR-5MS ( $30 \mathrm{~m} \times 0.25 \mathrm{~mm}$ i.d., $0.25 \mu \mathrm{m}$ film thickness) and the carrier gas was helium, at a $1 \mathrm{~mL} \mathrm{\textrm {min } ^ { - 1 }}$ rate. The analysis was performed according to the literature [9] with some modifications. The oven temperature was adapted to $110^{\circ} \mathrm{C}$ and then was increased at $205^{\circ} \mathrm{C}$ at a rate of $4{ }^{\circ} \mathrm{C} \mathrm{min}^{-1}$, followed by an increment of $1{ }^{\circ} \mathrm{C} \mathrm{min}-1$ up to $215^{\circ} \mathrm{C}$ and, up to $250{ }^{\circ} \mathrm{C}$ with a step of $4{ }^{\circ} \mathrm{C} \mathrm{min}^{-1}$. Finally, the temperature of $250^{\circ} \mathrm{C}$ was kept constant for $15 \mathrm{~min}$. The transfer line and injector temperatures were maintained at 260 and $220^{\circ} \mathrm{C}$, respectively. The injection volume was $1 \mu \mathrm{L}$ in a split-less mode. The peak identification was carried out with the Wiley 275 mass spectra library, its mass-spectral data, and arithmetic index provided by Adams 0.7 HP. 


\subsection{Spectroscopic Indices $\left(K_{232}, K_{268}, K_{270}, \Delta K\right)$}

$\mathrm{K}_{232}, \mathrm{~K}_{268}$, and $\mathrm{K}_{270}$ extinction coefficients were measured from the absorption of the samples in the UV region at 232, 268, and $270 \mathrm{~nm}$ respectively, with a UV-Vis (Cary 60, Agilent spectrophotometer). The samples were prepared according to ISO 3656:2011.

\subsection{HPLC-DAD and LC-MS Analysis}

Phenolic extracts were analyzed on high-pressure liquid chromatography (HPLC) Agilent 1100 series (Agilent Corporation, California, MA, USA) with a diode array detector (DAD). The system was connected to a computer and HP Chemstation software.

They were also analyzed on a Shimadzu LC/MS-2010A (Kyoto, Japan) equipped with an LC-10ADvp binary pump, a DGU-14A degasser, a SIL-10ADvp autosampler, an SPD-M10Avp Photo Diode Array Detector, and a quadrupole mass detector (MSD) with an electron spray ion source (MS-ESI, Electrospray Ionization). The system was connected to a computer and Shimatzu version 3.40 .307 software for chromatographic processing. The detector was set to negative ion operation mode under these conditions: ionization source temperature CDL (curved desolvation line): $300{ }^{\circ} \mathrm{C}$, mist gas flow $\left(\mathrm{N}_{2}\right): 1.5 \mathrm{~L} \mathrm{~min}^{-1}$, drying gas pressure $\left(\mathrm{N}_{2}\right)$ : $0.1 \mathrm{MPa}\left(10 \mathrm{~L} \mathrm{~min}^{-1}\right.$ flow), heat block temperature: $300^{\circ} \mathrm{C}$, mist area potential: $-2.5 \mathrm{kV}$, CDL voltage $-20 \mathrm{~V}$, detector voltage: $-1.55 \mathrm{kV}$, scan area: $50-1000 \mathrm{~m} / z$, and scan speed: $6000 \mathrm{amu} \mathrm{s}^{-1}$.

A reversed-phase column Supelco (Discovery HS C18) (Darmstadt, Germany), length $250 \mathrm{~mm}$, internal diameter $4 \mathrm{~mm}$ with material porosity of $5 \mu \mathrm{m}$ was used and it eluted the analytes at a flow rate of $1 \mathrm{~mL} \mathrm{~min}-1$. The following gradient of mobile phase $\mathrm{A}$ ( $0.1 \%$ formic acid in water) and mobile phase B $(0.1 \%$ formic acid in methanol) was used for the analysis. The program followed was $0-1 \mathrm{~min}, 5 \%$ solvent (B), $1-5 \mathrm{~min}, 10 \%$ solvent (B), 6-15 min, 33\% solvent (B), 16-25 min, 41\% solvent (B), 26-35 min, 62\% solvent (B), 36-42 min, 66\% solvent (B), 43-55 min, 100\% solvent (B), 56-65 min, 5\% solvent (B). Chromatograms were recorded at wavelengths 280, 320, 360, and $520 \mathrm{~nm}$ [21].

\subsection{FTIR Spectroscopy}

Fourier-transform infrared (FTIR) spectra were obtained using a Thermo Nicolet 6700 FTIR (Thermo Electron Corporation, Madison, WI, USA) equipped with a deuterated triglycine sulfate (DTGS) detector. The spectra were obtained with the diffuse reflectance infrared Fourier-transform spectroscopy (DRIFTS) technique. The speed of the interferometer moving mirror was $0.6329 \mathrm{~mm} \mathrm{~s}^{-1}$. Spectra were recorded with a resolution of $4 \mathrm{~cm}^{-1}$ and 100 scans. Before the analysis of each sample, the background was recorded. Triple FTIR spectra of each sample were obtained, using a different subsample each time.

FTIR spectra were smoothed using the Savitsky-Golay algorithm and their baselines were corrected. These pre-treatments were performed with "automatic smoothing" (5-point moving second-degree polynomial) and "baseline correction" (second-degree polynomial, twenty iterations) functions. Finally, using the "statistical spectra" function, the mean of three spectra for each sample was calculated and normalized (absorbance maximum value of 1). Spectrum processing was performed using the software OMNIC ver.9.1 (Thermo Fisher Scientific Inc., Waltham, MA, USA).

\subsection{Raman Spectroscopy}

A DeltaNu Advantage 785 visible-infrared Raman spectrometer (DeltaNu Inc., Laramie, WY, USA) equipped with a $785 \mathrm{~nm}$ diode laser for excitation with a maximum output power of $71.6 \mathrm{~mW}$ was used to record the spectra. Each spectrum was a $10 \mathrm{~s}$ acquisition over the spectral range of $2000-200 \mathrm{~cm}^{-1}$ using a resolution of $8 \mathrm{~cm}^{-1}$. The spectrometer was accompanied by NuSpec software. Raman spectra processing was performed as FTIR spectra. 


\subsection{Statistical Analysis}

All the experiments were done in triplicate and the results are given as mean \pm standard deviation (SD).

\section{Results and Discussion}

\subsection{Grape Seed Oil Analysis}

The grape seed oil yields differ for each grape variety tested and more information is presented in Figure 1. Higher yields were assigned to Robola from Zakynthos, yielding $8.77 \pm 0.18 \% w / w$, followed by Cabernet Sauvignon from Corfu, $8.11 \pm 0.18 w / w$. Lower yields were found in cultivars of Robola coming from the PDO of Robola in Cephalonia, ranging from $5.26 \pm 0.33$ to $7.01 \pm 0.85 \% w / w$. Other authors have pointed out that yields are closely related to two factors, including the variety tested [19] and the extraction method followed [9].

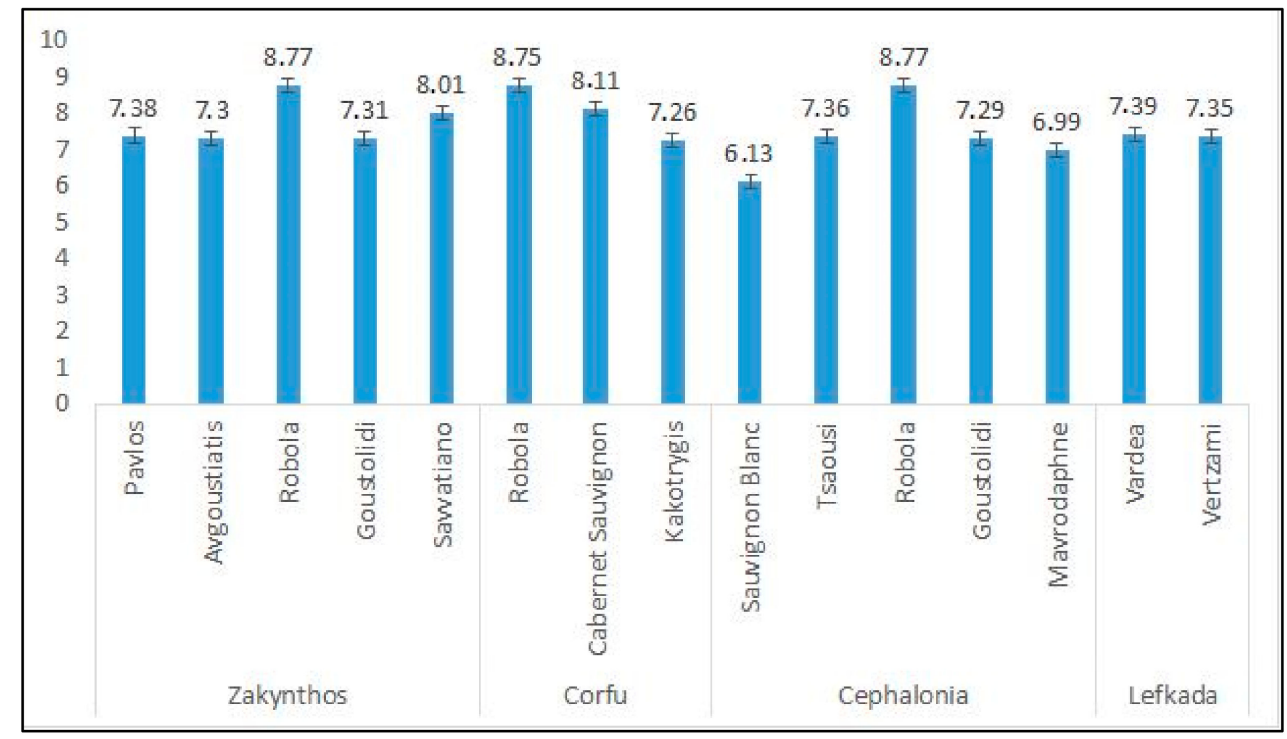

Figure 1. Grape seed oils yields $(\% w / w)$ for main grape varieties tested.

The tentative identity of the fatty acid profiles (\% abundance) from characteristic wine by-products varieties of the Ionian Islands are presented in Table 1. Grape seed oils had profile with a valuable source of unsaturated fatty acids (SFAs). Particularly, the FAMEs composition of the grape seed oils varied between the different varieties and cultivars. Linoleic fatty acid (C18:2) was the most abundant, followed by oleic fatty acid (C18:1), palmitic fatty acid (C16:0), and last, stearic fatty acid (C18:0). Other fatty acids found in the samples in smaller amounts were myristic (C14:0) and palmitoleic (C16:1). Linoleic fatty acid ranged from $53.28 \pm 1.24$ to $57.05 \pm 1.40 \%$ in Robola cultivars coming from the PDO of Robola in Cephalonia. Other varieties appeared to be higher in the abundance of linoleic fatty acid. For example, Tsaousi and Sauvignon Blanc from Cephalonia, Cabernet from Corfu, and Robola from Zakynthos had $60.95 \pm 1.65 \%, 60.82 \pm 2.45 \%, 59.66 \pm 0.84 \%$, and $59.26 \pm 0.91 \%$, respectively. On the other hand, oleic fatty acids were the constituent with the second highest abundance. For example, the cultivar of Robola from Cephalonia had content from $22.41 \pm 0.76$ to $25.44 \pm 1.36 \%$. High oleic fatty acid content combined with low linoleic fatty acid content appears to be a feature common for grape seed oils, as other studies have mentioned [19]. 
Table 1. Tentative identity of fatty acid profiles (\% abundance) from characteristic wine by-products varieties of the Ionian Islands.

\begin{tabular}{|c|c|c|c|c|c|c|c|c|c|}
\hline $\begin{array}{l}\text { Fatty Acids Chemical } \\
\text { Formula }^{\text {a }}\end{array}$ & $\begin{array}{c}\text { Avgoustiatis } \\
(\%)\end{array}$ & $\begin{array}{l}\text { Kakotrygis } \\
(\%)\end{array}$ & $\begin{array}{l}\text { Mavrodaphne } \\
(\%)\end{array}$ & $\begin{array}{c}\text { Paul } \\
(\%)\end{array}$ & $\begin{array}{c}\text { Robola } \\
(\%)\end{array}$ & $\begin{array}{c}\text { Goustolidi } \\
(\%)\end{array}$ & $\begin{array}{c}\text { Sauvingnon Blanc } \\
(\%)\end{array}$ & $\begin{array}{l}\text { Tsaousi } \\
(\%)\end{array}$ & $\begin{array}{c}\text { Cabernet Sauvignon } \\
(\%)\end{array}$ \\
\hline $\mathrm{C} 12: 0$ & $0.04 \pm 0.00$ & $0.04 \pm 0.01$ & $0.04 \pm 0.00$ & $0.05 \pm 0.00$ & $0.03 \pm 0.00$ & $0.04 \pm 0.00$ & $0.03 \pm 0.00$ & $0.03 \pm 0.00$ & $0.03 \pm 0.01$ \\
\hline C14:0 & $0.23 \pm 0.02$ & $0.24 \pm 0.01$ & $0.27 \pm 0.00$ & $0.22 \pm 0.00$ & $0.17 \pm 0.00$ & $0.25 \pm 0.01$ & $0.16 \pm 0.00$ & $0.18 \pm 0.00$ & $0.25 \pm 0.05$ \\
\hline $\mathrm{C} 16: 0$ & $14.4 \pm 0.32$ & $14.97 \pm 0.31$ & $15.03 \pm 0.05$ & $14.13 \pm 0.06$ & $13.4 \pm 0.09$ & $15.34 \pm 0.11$ & $12.47 \pm 0.60$ & $12.86 \pm 0.79$ & $14.23 \pm 1.30$ \\
\hline C17:0 & $0.09 \pm 0.01$ & $0.09 \pm 0.03$ & $0.09 \pm 0.00$ & $0.09 \pm 0.00$ & $0.09 \pm 0.01$ & $0.08 \pm 0.01$ & $0.12 \pm 0.01$ & $0.08 \pm 0.01$ & $0.09 \pm 0.00$ \\
\hline C18:0 & $5.06 \pm 0.00$ & $4.81 \pm 0.00$ & $4.49 \pm 0.00$ & $4.78 \pm 0.00$ & $4.78 \pm 0.03$ & $4.21 \pm 0.01$ & $7.70 \pm 0.05$ & $4.23 \pm 0.03$ & $6.39 \pm 0.03$ \\
\hline C20:0 & $0.10 \pm 0.00$ & $0.09 \pm 0.00$ & $0.09 \pm 0.00$ & $0.09 \pm 0.00$ & $0.09 \pm 0.00$ & $0.07 \pm 0.01$ & $0.16 \pm 0.00$ & $0.10 \pm 0.00$ & $0.13 \pm 0.01$ \\
\hline $\mathrm{C} 15: 1$ & $0.04 \pm 0.00$ & $0.05 \pm 0.00$ & $0.05 \pm 0.00$ & $0.06 \pm 0.00$ & $0.04 \pm 0.00$ & $0.05 \pm 0.00$ & $0.05 \pm 0.00$ & $0.05 \pm 0.00$ & $0.04 \pm 0.01$ \\
\hline C16:1 & $0.58 \pm 0.00$ & $0.58 \pm 0.00$ & $0.66 \pm 0.05$ & $0.65 \pm 0.06$ & $0.61 \pm 0.00$ & $0.65 \pm 0.03$ & $0.26 \pm 0.04$ & $0.46 \pm 0.05$ & $0.40 \pm 0.01$ \\
\hline C17:1 & $0.10 \pm 0.00$ & $0.09 \pm 0.00$ & $0.10 \pm 0.00$ & $0.10 \pm 0.00$ & $0.08 \pm 0.00$ & $0.09 \pm 0.00$ & $0.09 \pm 0.00$ & $0.08 \pm 0.01$ & $0.08 \pm 0.03$ \\
\hline C18:1 & $22.87 \pm 1.33$ & $22.45 \pm 1.38$ & $25.27 \pm 0.99$ & $22.52 \pm 0.83$ & $24.29 \pm 0.59$ & $21.74 \pm 0.28$ & $17.55 \pm 2.37$ & $20.44 \pm 1.60$ & $18.42 \pm 1.23$ \\
\hline C20:1 & $0.15 \pm 0.00$ & $0.13 \pm 0.00$ & $0.12 \pm 0.03$ & $0.14 \pm 0.00$ & $0.15 \pm 0.00$ & $0.12 \pm 0.00$ & $0.18 \pm 0.03$ & $0.17 \pm 0.05$ & $0.15 \pm 0.01$ \\
\hline $\mathrm{C} 16: 2$ & $0.00 \pm 0.00$ & $0.02 \pm 0.00$ & $0.02 \pm 0.00$ & $0.02 \pm 0.00$ & $0.01 \pm 0.00$ & $0.02 \pm 0.00$ & $0.03 \pm 0.00$ & $0.02 \pm 0.00$ & $0.02 \pm 0.00$ \\
\hline C18:2 & $56.19 \pm 1.10$ & $56.35 \pm 0.02$ & $53.28 \pm 1.24$ & $57.05 \pm 1.40$ & $59.26 \pm 0.91$ & $57.26 \pm 1.08$ & $60.82 \pm 2.45$ & $60.95 \pm 1.65$ & $59.66 \pm 0.84$ \\
\hline SFAs & $19.97 \pm 0.06$ & $20.29 \pm 0.05$ & $20.06 \pm 0.01$ & $19.40 \pm 0.01$ & $18.59 \pm 0.02$ & $20.04 \pm 0.02$ & $20.67 \pm 0.09$ & $17.53 \pm 0.12$ & $21.15 \pm 0.20$ \\
\hline MUFAs & $23.77 \pm 0.22$ & $23.33 \pm 0.23$ & $26.23 \pm 0.18$ & $23.49 \pm 0.15$ & $25.18 \pm 0.10$ & $22.68 \pm 0.17$ & $18.15 \pm 0.22$ & $21.23 \pm 0.29$ & $19.10 \pm 0.22$ \\
\hline
\end{tabular}


For the rest of the varieties tested, oleic fatty acid ranged from $17.55 \pm 2.37 \%$ in Sauvignon Blanc from Cephalonia to $21.74 \pm 0.28 \%$ in Goustolidi from Zakynthos. Both linoleic and oleic fatty acids total $78-82 \%$ of FAMEs, which is similar to the fatty acid composition of safflower oil, which is related to the genotype and the environment was chosen $[26,27]$.

\subsection{Grape Seed Oil Antioxidant Activity}

The antioxidant activity of grape seed oil was estimated by DPPH and ABTS assays as presented in Table 2. The varieties of Tsaousi from Cephalonia, Goustolidi from Zakynthos, and four of the cultivars of the PDO of Robola in Cephalonia exhibited more than $60 \%$ of the scavenging effect of the DPPH radicals, while the before-mentioned samples inhibited more than $90 \%$ of the effect of the ABTS $^{\bullet+}$ radical, except in the case of Tsaousi from Cephalonia, where the scavenging effect of the ABTS ${ }^{\bullet+}$ radical was $64.8 \%$. The rest of the grape seed oils tested for their antiradical activity showed the scavenging effect of the DPPH radicals ranging from 42.95 to $56.25 \%$, while they succeed better in eradicating the $\mathrm{ABTS}^{\bullet+}$, with an inhibition rate from 88.16 to $94.20 \%$.

Table 2. Antioxidant activity of grape seed oil extracts.

\begin{tabular}{|c|c|c|c|c|c|c|}
\hline \multirow[b]{2}{*}{ Variety } & \multirow[b]{2}{*}{ Region } & \multirow[t]{2}{*}{ Total Phenolics } & \multicolumn{4}{|c|}{ Antioxidant Activity } \\
\hline & & & ${ }^{b}$ DPPH & ${ }^{c}$ DPPH & ${ }^{\mathrm{d}}$ ABTS & e ABTS \\
\hline Sauvignon Blanc & Cephalonia & $24.17 \pm 0.20$ & 0.89 & $56.26 \pm 2.30$ & $92.75 \pm 3.34$ & 0.94 \\
\hline Tsaousi & Cephalonia & $18.75 \pm 0.19$ & 0.96 & $60.71 \pm 2.60$ & $64.88 \pm 1.27$ & 0.64 \\
\hline Robola & Cephalonia & $17.50 \pm 0.09$ & 0.67 & $42.95 \pm 1.64$ & $94.20 \pm 3.49$ & 0.96 \\
\hline Robola & Zakynthos & $18.33 \pm 0.12$ & 0.87 & $55.41 \pm 3.90$ & $88.16 \pm 2.14$ & 0.89 \\
\hline Goustolidi & Zakynthos & $6.11 \pm 0.19$ & 1.04 & $65.90 \pm 3.20$ & $94.16 \pm 3.88$ & 0.96 \\
\hline Robola & Cephalonia & $22.50 \pm 0.15$ & 1.07 & $67.73 \pm 3.19$ & $91.55 \pm 3.46$ & 0.93 \\
\hline Robola & Cephalonia & $13.28 \pm 0.13$ & 0.95 & $60.17 \pm 3.57$ & $97.63 \pm 3.94$ & 1.00 \\
\hline Robola & Cephalonia & $20.83 \pm 0.15$ & 0.98 & $61.88 \pm 2.12$ & $95.15 \pm 3.26$ & 0.97 \\
\hline Robola & Cephalonia & $30.00 \pm 0.14$ & 1.00 & $63.57 \pm 3.69$ & $94.60 \pm 3.34$ & 0.96 \\
\hline Mavrodaphne & Cephalonia & $29.17 \pm 0.09$ & 0.68 & $43.21 \pm 2.09$ & $94.55 \pm 3.12$ & 0.96 \\
\hline Robola & Cephalonia & $10.56 \pm 0.08$ & 0.77 & $49.31 \pm 2.12$ & $89.44 \pm 2.54$ & 0.91 \\
\hline Robola & Cephalonia & $22.22 \pm 0.10$ & 0.78 & $49.86 \pm 2.67$ & $92.91 \pm 3.22$ & 0.95 \\
\hline Avgoustiatis & Zakynthos & $18.33 \pm 0.12$ & 0.71 & $45.14 \pm 2.55$ & $92.87 \pm 3.14$ & 0.94 \\
\hline Paul & Zakynthos & $35.00 \pm 0.19$ & 0.88 & $55.56 \pm 3.29$ & $91.75 \pm 3.69$ & 0.93 \\
\hline Avgoustiatis, Skiadopoulos & Zakynthos & $40.00 \pm 0.20$ & 0.79 & $50.14 \pm 3.64$ & $90.91 \pm 3.05$ & 0.92 \\
\hline Avgoustiatis, Katsali & Zakynthos & $37.50 \pm 0.13$ & 0.77 & $48.75 \pm 2.67$ & $92.03 \pm 3.24$ & 0.94 \\
\hline Kakotrygis & Corfu & $19.17 \pm 0.12$ & 0.87 & $55.42 \pm 2.40$ & $93.85 \pm 3.67$ & 0.96 \\
\hline Cabernet Sauvignon & Corfu & $46.67 \pm 0.10$ & 0.86 & $54.58 \pm 2.13$ & $91.62 \pm 3.16$ & 0.93 \\
\hline Syrah & Corfu & $18.33 \pm 0.09$ & 0.88 & $55.69 \pm 2.09$ & $90.07 \pm 3.10$ & 0.91 \\
\hline Matzavi & Corfu & $16.67 \pm 0.05$ & 0.88 & $55.97 \pm 1.30$ & $86.43 \pm 2.88$ & 0.88 \\
\hline Robola & Corfu & $22.50 \pm 0.12$ & 0.82 & $52.22 \pm 1.22$ & $88.81 \pm 3.09$ & 0.90 \\
\hline Moschato white & Corfu & $15.83 \pm 0.16$ & 0.74 & $47.22 \pm 2.43$ & $88.95 \pm 2.49$ & 0.90 \\
\hline Mavrodaphne & Cephalonia & $24.17 \pm 0.06$ & 0.88 & $55.56 \pm 2.77$ & $93.01 \pm 2.39$ & 0.95 \\
\hline Avgoustiatis, Pyrarnis & Zakynthos & $30.83 \pm 0.09$ & 0.67 & $43.06 \pm 1.31$ & $87.97 \pm 2.19$ & 0.89 \\
\hline Vertzami & Lefkada & $28.33 \pm 0.05$ & 0.69 & $43.75 \pm 2.39$ & $88.81 \pm 2.88$ & 0.90 \\
\hline Vardea & Lefkada & $35.83 \pm 0.16$ & 0.79 & $50.00 \pm 2.49$ & $89.37 \pm 2.61$ & 0.91 \\
\hline Pavlos, Cardinal, Zambella & Zakynthos & $18.33 \pm 0.12$ & 0.72 & $45.69 \pm 2.61$ & $89.65 \pm 2.77$ & 0.91 \\
\hline
\end{tabular}

${ }^{\mathrm{a}} \mathrm{C}_{\mathrm{TPC}}\left(\mathrm{mg} \mathrm{mL}^{-1}\right) \pm \mathrm{SD}$ : concentration of TPC expressed as mg GAE $\mathrm{mL}^{-1}$ of extract. ${ }^{\mathrm{b}} \mathrm{DPPH}\left(\mathrm{mg}\right.$ Trolox $\left.\mathrm{g}^{-1}\right)$ : the inhibition of free radical DPPH expressed as mg Trolox equivalents $\mathrm{g}^{-1}$ dry weight. ${ }^{c} \mathrm{DPPH}$ : (I \%) \pm SD: the \% inhibition of free radical DPPH. ${ }^{\mathrm{d}}$ ABTS $(\mathrm{I} \%) \pm$ SD: the \% inhibition of free radical ABTS. ${ }^{\mathrm{e}}$ ABTS $\left(\mathrm{mg}^{-1}\right.$ Trolox $\left.\mathrm{g}^{-1}\right)$ : the inhibition of free radical ABTS expressed as mg Trolox equivalents $\mathrm{g}^{-1}$ dry weight.

Similar to previous research [28,29], results of this study indicate that grape seed oils are in phenolics due to the low solubility of phenolics in the lipid fraction, as most of the phenolic compounds remain in the defatted grape seed particles which have a phenolic concentration at least 100-fold higher than the phenolic concentration in the oil [30]. TPC in grape seed oils by soxhlet extraction was found to vary from 6.11-46.67 $\mathrm{mg} \mathrm{GAE}^{-1}$ [31,32]. 
From the results, we conclude that the antioxidant activity of the extracts is influenced by the assay, the extraction method, and the chemical compounds they contain. Other probes, such as DPPH assay, have greater sensitivity to aqueous extracts, while others, such as ABTS, have greater sensitivity to lipophilic extracts. Finally, due to the complexities of the extract's structure and the synergistic action of the components, detecting the antioxidant activity of a single component is nearly impossible. As a result, determining antioxidant activity using at least two different methods is a mandatory step in order to obtain comparable results and relate the content of phenolic compounds to antioxidant activity.

\subsection{Grape Seed Oil Spectroscopic Indices}

The spectroscopic indicator, $\mathrm{K}_{232}$ was more than 2.50 for three samples, including two of the Robola cultivars of the PDO of Robola in Cephalonia and Tsaousi from Cephalonia. In all the other samples $K_{232}$ was less or equal to 2.50. Moreover, six of the grape seed oils' $\Delta \mathrm{K}$ were equal to 0.1 , and for the other six more than 0.2 . According to the EU regulation [33] oils with $\Delta \mathrm{K}$ above 0.1 are not subject to the category "extra virgin/virgin olive oil". K indices can be misleading if used as the only criterion of the oil quality other than olive oil and therefore must be combined with the other quality parameters as well.

\subsection{Raman Spectroscopy in Grape Seed Oils}

A representative Raman spectrum from grape seed oil is presented in Figure 2. The grape seed oils gave two strong peaks, one at $1655 \mathrm{~cm}^{-1}$ and the other at $1444 \mathrm{~cm}^{-1}$. A peak at $1655 \mathrm{~cm}^{-1}$ mentioned unsaturated cis double bonds, while the peak at $1444 \mathrm{~cm}^{-1}$ belongs to $\left(-\mathrm{CH}_{2}\right)$ scissor and twist vibration of fatty acids. Its peaks tend to be stronger as the chain length of the fatty acids increases [34]. The peaks between 1400 and $800 \mathrm{~cm}^{-1}$ belong to aliphatic stretches [35].

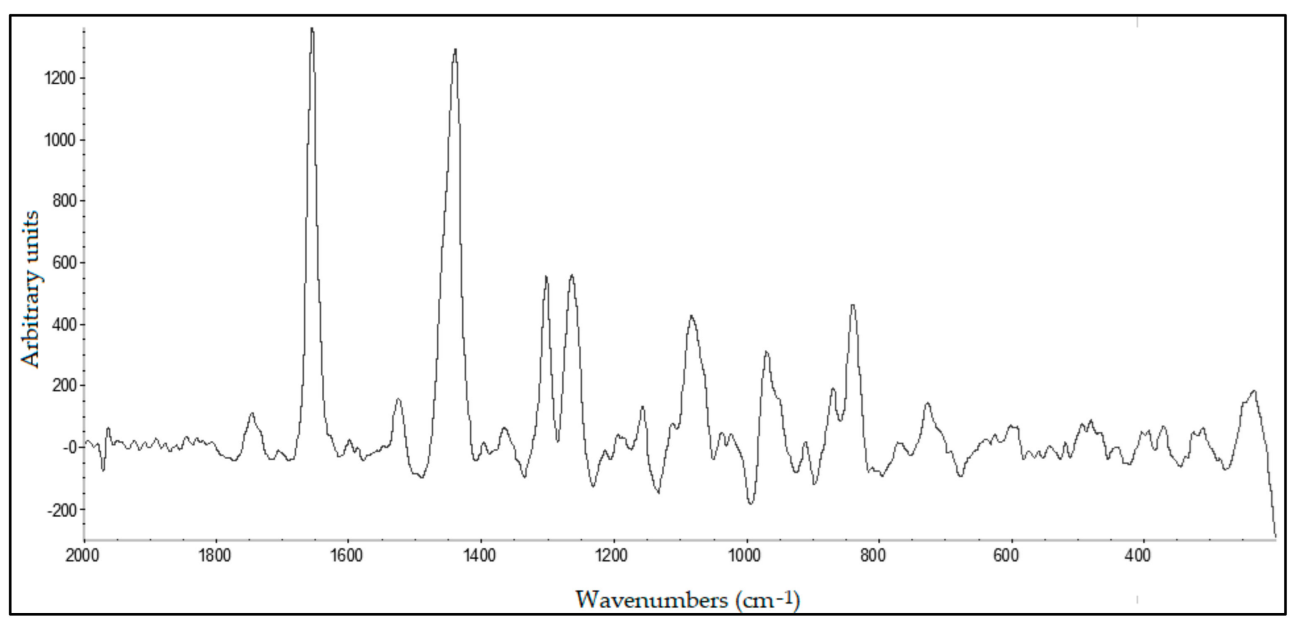

Figure 2. Raman spectrum of Robola grape seed oil from Cephalonia.

\subsection{Grape Skin Analysis}

Pretreatment of the samples before extraction had an important role in the recovery of bioactive compounds for further analysis. Qualitative determination of phenols according to their structure showed a characteristic absorption spectrum in UV-Vis. In particular, hydroxybenzoic acids, flavonols, and procyanidins were detected at $280 \mathrm{~nm}$, stilbenes, hydroxycinnamic acids, and their esters at $320 \mathrm{~nm}$, flavonols, and their glycosides at $360 \mathrm{~nm}$. UV-Vis spectra of flavonoids showed the two absorption bands I and II. Zone I had an absorbance range of 300-370 nm due to the structure of rings B and C while band II had an absorbance range of $250-300 \mathrm{~nm}$ due to the A-ring of the flavonoids. In the absorbance range of 260-280 nm, we also confirmed the existence of phenolic compounds and particular phenolic acids [25]. Finally, absorptions at $520 \mathrm{~nm}$ were attributed to anthocyanins. 
Determination of phenolic compounds was identified by LC-MS analysis (Figure 3), comparing mass spectrum and the UV spectrum with standards. Peaks were attributed to monomeric 3-flavanols as well as monomeric, dimeric, and trimeric proanthocyanidins. Specifically, Robola grape skin extracts were rich in proanthocyanidins, catechin, epicatechin, a glycoside of kaempferol, and 3-glucuronide of quercetin (Table 3).

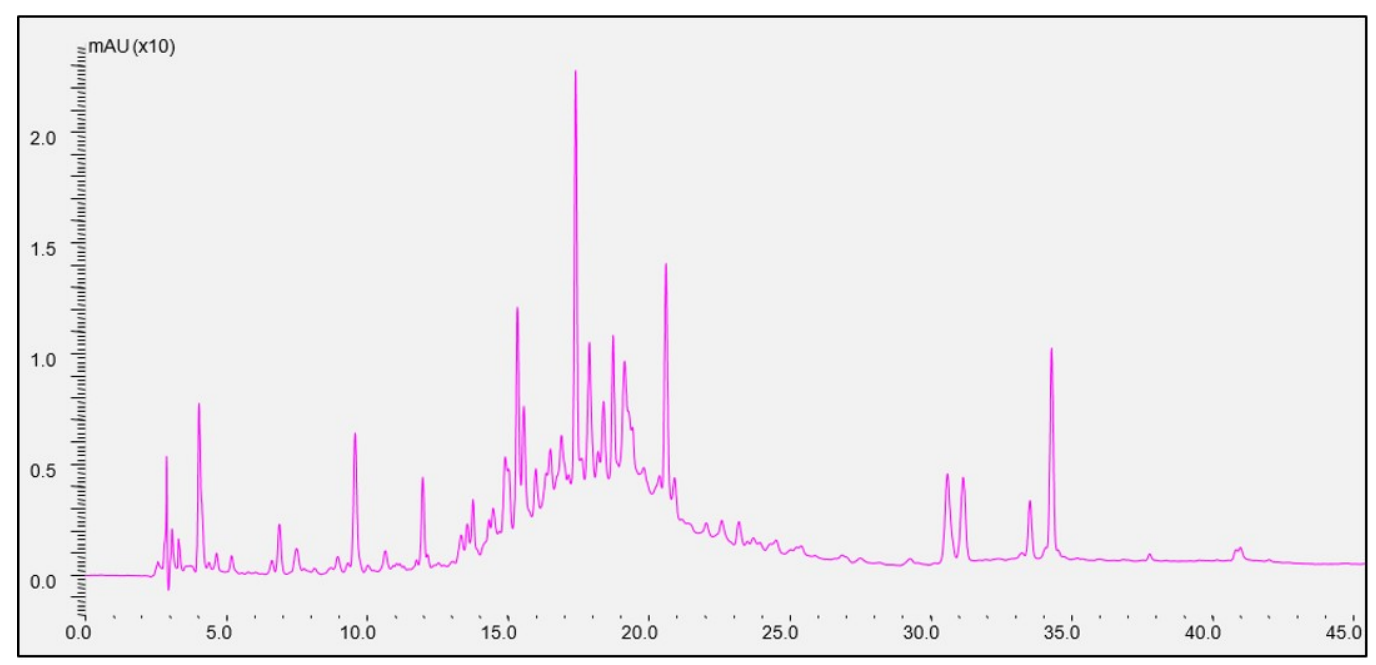

Figure 3. LC-MS of polyphenolic fraction from wine by-products of the Robola variety.

Grape skins from white varieties have a higher content of trans-caftaric acid than red grapes [36]. Quercetin-3-O-glucuronide and quercetin-3-O-glucoside remain at relatively high levels in all varieties [37]. The content of myricetin has not been detected in most white varieties. This could be due to the absence of the enzyme flavonoid- $3^{\prime}, 5^{\prime}$-hydroxylase in white grape varieties $[38,39]$. Tannins represent a significant content of the bioactive phytochemicals in vinification residues and available records describe the presence of procyanidin dimers B1, B2, B3, and B4 and procyanidin trimers C1, C2, and C3. Grape skin extracts contain high oligomeric proanthocyanidins [40], which can combine with gallic acid to form gallate esters, and ultimately glycosides [41].

The polyphenolic composition of by-products depends on grape cultivar, vintage effect, grape maturity, and winemaking methods [42]. Heat drying is also a significant factor to consider, especially when applied on an industrial scale, because it affects phenolic stability [43]. These by-products are perishable, and when they are produced in high masses they need rapid stabilization by drying. In addition, the balance between costs and the final quality of the dried by-product must be considered [43]. Another significant factor affecting phenolic isolation is the effectiveness of some solvent's extractors. In this study, a mixture of water and glycerol is suggested, although polyphenolic extracts were also obtained with other aqueous mixtures of ethanol or acetone with similar effectiveness [44]. In each case, the use of aqueous solutions shows qualitative and quantitative differences.

Despite the cultivar, grape skins can still contain large amounts of phenolic compounds, both after red winemaking and white winemaking. Grape skins from four cultivars from Italy after fermentative maceration still had a high content of total and monomer anthocyanins and lower content of flavans and tannins [45]. However, in our study, the analysis of winery by-products suggests differences in phenolic content from red and white varieties. Guaita et al., 2019 [45] reported that the higher homogeneity of polyphenolic composition between the by-products of different grape cultivars is also the consequence of the management of the fermentative maceration performed by the various wineries. They also stated that these differences may be due to modalities of the by-products mixing operations, the adsorbent effect of the yeast strain, the use of maceration enzymes, the temperature, and the amount of oxygen supplied. This observation enables us to manage the red and white varieties as separate materials. 
Table 3. Tentative identity of major polyphenols from characteristic wine by-products varieties of the Ionian Islands.

\begin{tabular}{|c|c|c|c|c|c|c|c|c|c|c|c|}
\hline Peak Rt & UV-Vis & [M-H]- & [M-H]- & Tentative Identity & Robola & Avgoustiatis & Mavrodaphne & Paul & Cabernet Sauvignon & Kakotrygis & Goustolid \\
\hline 7.4 & 274 & 146 & 148 & cinnamic acid & + & + & + & + & - & + & + \\
\hline 9.5 & $215 ; 270$ & 168 & 170 & gallic acid & ++ & ++ & + & ++ & + & ++ & ++ \\
\hline 13.5 & 217 & 330 & 332 & monogaloglucose & + & ++ & + & - & - & + & + \\
\hline 15.0 & $217 ; 277$ & 576 & 578 & procyanidin dimer & + & + & ++ & + & - & + & + \\
\hline 15.3 & 278 & 577 & 578 & procyanidin dimer & + & + & ++ & + & - & + & + \\
\hline 15.5 & $286 ; 328$ & 310 & 312 & caftaric acid & ++ & - & + & - & - & + & ++ \\
\hline 15.9 & $218 ; 277$ & 865 & 866 & procyanidin trimer & + & + & ++ & + & - & + & + \\
\hline 16.8 & $220 ; 277$ & 576 & 578 & procyanidin dimer & + & + & ++ & + & - & + & + \\
\hline 17.3 & 278 & 288 & 290 & catechin & ++ & + & + & ++ & + & ++ & ++ \\
\hline 17.8 & $278 ; 375$ & 576 & 578 & procyanidin dimer & + & + & ++ & + & + & + & + \\
\hline 18.3 & $223 ; 271$ & 443 & 442 & epicatechin gallate & + & + & ++ & + & + & + & + \\
\hline 19.1 & $219 ; 278$ & 865 & 866 & procyanidin trimer & + & + & ++ & + & - & + & + \\
\hline 19.2 & $222 ; 278$ & 865 & 866 & catechin trimer & + & + & + & + & - & + & + \\
\hline 19.3 & $222 ; 278$ & 576 & 578 & procyanidin dimer & + & + & + & + & + & + & + \\
\hline 20.5 & 278 & 288 & 290 & epicatechin & + & ++ & + & + & + & + & + \\
\hline 25.0 & 226 & 163 & 164 & p-coumaric acid & + & - & + & - & - & - & + \\
\hline 31.1 & $226 ; 355$ & 609 & 610 & rutin & ++ & + & + & - & - & - & ++ \\
\hline 33.5 & $264 ; 348$ & 446 & 448 & kaempferol-7-O-glucoside & + & + & ++ & + & - & + & + \\
\hline 34.2 & $265 ; 349$ & 446 & 448 & kaempferol-3-O-galactoside & ++ & + & ++ & + & - & + & ++ \\
\hline 34.4 & $226 ; 350$ & 477 & 448 & isorhamnentin-3-O-glycoside & ++ & + & ++ & - & + & - & ++ \\
\hline 37.7 & 373 & 301 & 302 & quercetin & + & + & ++ & - & - & - & + \\
\hline
\end{tabular}




\subsection{Grape Skin Antioxidant Activity}

The results of antioxidant activity are displayed in Table 4 and confirmed the high TPC performance of grape skins. The results depended on the variety. Differences also exist due to soil or climatic conditions, winery treatment, or vinification [42]. Nevertheless, it appeared that all the varieties had high TPC even after their vinification with an average of (22.94 mg GAE mL $\left.{ }^{-1}\right)$. It was observed that the higher TPC was in the red Cabernet Sauvignon variety from Corfu ( $32.60 \mathrm{mg} \mathrm{GAE} \mathrm{mL}^{-1}$ ) while lower absorptions appeared in white varieties. Similar results were observed in antiradical activity methods. The rest of the grape skin extracts tested for their antiradical activity showed a scavenging effect of the DPPH radicals ranging from 25.43 to $53.20 \%$, while they succeed better in eradicating the ABTS, with an inhibition rate from 24.49 to $98.62 \%$.

Table 4. TPC and antioxidant activity of grape skin extracts.

\begin{tabular}{|c|c|c|c|c|c|c|c|}
\hline \multirow[b]{2}{*}{ Variety } & \multirow[b]{2}{*}{ Winery/Producer } & \multirow[b]{2}{*}{ Region } & \multirow{2}{*}{$\begin{array}{c}\text { Total Phenolics } \\
{ }^{\text {a }} \mathrm{C}_{\mathrm{TPC}}\end{array}$} & \multicolumn{4}{|c|}{ Antioxidant Activity } \\
\hline & & & & ${ }^{b} \mathbf{A}_{\mathrm{AR}}$ & ${ }^{c} \mathrm{DPPH}$ & d ABTS & e ABTS \\
\hline Sauvignon Blanc & Gentilini & Cephalonia & $10.56 \pm 0.01$ & 0.60 & $29.55 \pm 0.57$ & $24.49 \pm 1.18$ & 42.16 \\
\hline Tsaousi & Gentilini & Cephalonia & $14.72 \pm 0.01$ & 0.78 & $33.11 \pm 0.63$ & $32.30 \pm 1.43$ & 55.68 \\
\hline Robola & Gentilini/Fagias & Cephalonia & $25.00 \pm 0.02$ & 0.70 & $21.42 \pm 1.04$ & $55.52 \pm 0.85$ & 95.88 \\
\hline Robola & Grapsas & Zakynthos & $15.13 \pm 0.01$ & 1.14 & $40.72 \pm 1.33$ & $60.44 \pm 1.29$ & 104.39 \\
\hline Goustolidi & Grapsas & Zakynthos & $16.11 \pm 0.01$ & 0.90 & $42.73 \pm 0.65$ & $77.28 \pm 0.86$ & 133.55 \\
\hline Robola & Gentilini/Kokkinopilia & Cephalonia & $30.28 \pm 0.02$ & 0.65 & $19.94 \pm 0.07$ & $63.86 \pm 0.28$ & 110.33 \\
\hline Robola & Gentilini & Cephalonia & $28.00 \pm 0.01$ & 1.05 & $31.16 \pm 0.36$ & $98.04 \pm 0.14$ & 169.49 \\
\hline Robola & Gentilini/Xalkias & Cephalonia & $28.61 \pm 0.01$ & 0.86 & $25.93 \pm 0.88$ & $86.94 \pm 0.29$ & 150.28 \\
\hline Robola & Gentilini/Valsamata & Cephalonia & $33.33 \pm 0.02$ & 0.53 & $16.75 \pm 0.46$ & $58.74 \pm 1.05$ & 101.45 \\
\hline Mavrodaphne & Tavlianatos & Cephalonia & $28.89 \pm 0.01$ & 1.20 & $35.20 \pm 1.07$ & $97.06 \pm 1.33$ & 167.79 \\
\hline Robola & Gentilini/Lianos & Cephalonia & $10.56 \pm 0.01$ & 0.46 & $14.87 \pm 0.44$ & $43.35 \pm 3.84$ & 74.82 \\
\hline Robola & Gentilini & Cephalonia & $22.22 \pm 0.01$ & 0.79 & $23.89 \pm 0.98$ & $71.37 \pm 2.20$ & 123.32 \\
\hline Avgoustiatis & Grapsas & Zakynthos & $21.29 \pm 0.01$ & 0.88 & $26.39 \pm 0.09$ & $70.67 \pm 0.24$ & 122.11 \\
\hline Paul & Grapsas & Zakynthos & $32.22 \pm 0.03$ & 1.04 & $30.72 \pm 0.54$ & $85.31 \pm 2.15$ & 147.46 \\
\hline $\begin{array}{l}\text { Avgoustiatis, } \\
\text { Skiadopoulos }\end{array}$ & Kallinikos & Zakynthos & $15.30 \pm 0.01$ & 1.43 & $36.57 \pm 0.53$ & $90.07 \pm 0.90$ & 155.69 \\
\hline Avgoustiatis, Katsali & Kallinikos & Zakynthos & $18.67 \pm 0.01$ & 1.15 & $33.99 \pm 0.26$ & $86.80 \pm 0.83$ & 150.04 \\
\hline Kakotrygis & Theotokis & Corfu & $22.64 \pm 0.01$ & 1.14 & $33.70 \pm 0.46$ & $75.52 \pm 0.76$ & 130.51 \\
\hline Cabernet Sauvignon & Theotokis & Corfu & $32.60 \pm 0.01$ & 1.47 & $42.73 \pm 1.20$ & $91.09 \pm 2.47$ & 157.46 \\
\hline Syrah & Theotokis & Corfu & $18.40 \pm 0.01$ & 0.40 & $15.89 \pm 0.09$ & $46.37 \pm 0.76$ & 80.05 \\
\hline Matzavi & Theotokis & Corfu & $16.99 \pm 0.01$ & 0.53 & $18.87 \pm 1.04$ & $54.35 \pm 2.08$ & 93.86 \\
\hline Robola & Theotokis & Corfu & $16.74 \pm 0.01$ & 0.88 & $27.69 \pm 1.05$ & $86.29 \pm 0.89$ & 149.15 \\
\hline Moschato white & Theotokis & Corfu & $13.30 \pm 0.01$ & 0.44 & $19.43 \pm 0.59$ & $67.61 \pm 1.98$ & 116.81 \\
\hline Mavrodaphne & Gentilini & Cephalonia & $29.36 \pm 0.01$ & 1.43 & $22.17 \pm 0.22$ & $\begin{array}{l}62.37 \pm 1.09 \\
1.014 \pm 1.04\end{array}$ & 107.75 \\
\hline Avgoustiatis, Pyrarnis & Gentilini & Zakynthos & $27.36 \pm 0.01$ & 1.22 & $38.10 \pm 0.14$ & $98.62 \pm 1.14$ & 170.50 \\
\hline Vertzami & Robotis & Lefkada & $29.10 \pm 0.01$ & 1.79 & $29.79 \pm 0.09$ & $90.60 \pm 0.46$ & 156.61 \\
\hline Vardea & Robotis & Lefkada & $35.67 \pm 0.02$ & 0.48 & $19.23 \pm 0.47$ & $71.34 \pm 4.03$ & 123.27 \\
\hline $\begin{array}{c}\text { Pavlos, Cardinal, } \\
\text { Zambella }\end{array}$ & Merkatis & Zakynthos & $26.55 \pm 0.02$ & 0.57 & $24.83 \pm 0.55$ & $65.29 \pm 1.52$ & 112.80 \\
\hline
\end{tabular}

${ }^{a} \mathrm{C}_{\mathrm{TPC}}\left(\mathrm{mg} \mathrm{mL}^{-1}\right) \pm \mathrm{SD}$ : concentration of TPC expressed as mg GAE mL ${ }^{-1}$ of extract. ${ }^{\mathrm{b}} \mathrm{A}_{\mathrm{AR}}$ : $\mathrm{A}_{\mathrm{AR}}$ expressed as $\mu \mathrm{mol}$ of $\mathrm{DPPH} \mathrm{g}^{-1}$ of dry weight. ${ }^{\mathrm{c}} \mathrm{DPPH}\left(\mathrm{mg}\right.$ Trolox $\mathrm{g}^{-1}$ ): the inhibition of free radical DPPH expressed as $\mathrm{mg}$ Trolox equivalents $\mathrm{g}^{-1} \mathrm{dry}^{\mathrm{d}} \mathrm{weight}{ }^{\mathrm{d}}$ ABTS (I \%) \pm SD: the $\%$ inhibition of free radical ABTS. ${ }^{\mathrm{e}}$ ABTS $\left(\mathrm{mg}^{\mathrm{T}}\right.$ Trolox $\left.\mathrm{g}^{-1}\right)$ : the inhibition of free radical ABTS expressed as mg Trolox equivalents $\mathrm{g}^{-1}$ dry weight.

It should be noted that the TPC is influenced, in particular, by the concentration of anthocyanins and flavans at a high and medium-low molecular weight. Guaita et al., 2019 [45] reported that another significant factor that affects the concentrations was the fermentative maceration because it can cause a strong reduction in the TPC of skins.

The results of TPC and antiradical activity are correlated $(p$-value $<0.05)$ as shown in Table 5. Bosso et al., 2020 [42] also reported correlations between the ABTS values determined and the corresponding TPC. Additionally, another study remarked that the above results are related to a limited number of tannins [46]. The variation in antiradical activity could be due to qualitative differences in the polyphenolic composition of the extracts as previously reported. 
Table 5. Correlations between TPC and antiradical activity methods.

\begin{tabular}{cccccc}
\hline Variables & ${ }^{\mathrm{a}} \mathbf{C}_{\text {TPC }}$ & ${ }^{\mathbf{b}} \mathbf{A}_{\text {AR }}$ & ${ }^{\mathrm{c}}$ DPPH & ${ }^{\mathrm{d}}$ ABTS & ${ }^{\mathrm{e}}$ ABTS \\
\hline${ }^{\mathrm{a}} \mathrm{C}_{\mathrm{TPC}}$ & 1 & 0.762 & 0.703 & 0.770 & 0.770 \\
${ }^{\mathrm{b}} \mathrm{A}_{\mathrm{AR}}$ & 0.762 & 1 & 0.686 & 0.632 & 0.632 \\
${ }^{\mathrm{c}}$ DPPH & 0.703 & 0.686 & 1 & 0.476 & 0.476 \\
${ }^{\mathrm{d}}$ ABTS & 0.770 & 0.632 & 0.476 & 1 & 1.000 \\
e ABTS & 0.770 & 0.632 & 0.476 & 1.000 & 1 \\
\hline
\end{tabular}

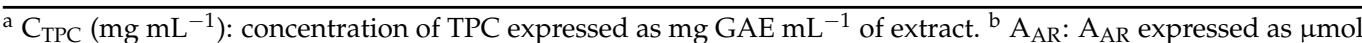
of DPPH g ${ }^{-1}$ of dry weight. ${ }^{c}$ DPPH ( $\mathrm{mg}^{2}$ Trolox $\left.\mathrm{g}^{-1}\right)$ : the inhibition of free radical DPPH expressed as $\mathrm{mg}$ Trolox equivalents $\mathrm{g}^{-1}$ dry weight. ${ }^{\mathrm{d}}$ ABTS (I \%): the \% inhibition of free radical ABTS. ${ }^{\mathrm{e}}$ ABTS (mg Trolox $\mathrm{g}^{-1}$ ): the inhibition of free radical ABTS expressed as mg Trolox equivalents $\mathrm{g}^{-1}$ dry weight.

\subsection{FTIR and Raman Spectroscopy of Grape Skins}

A representative FTIR spectrum from the grape skin sample is presented in Figure 4. The assignments of the major peaks are shown in Table 6. It was observed that the spectra showed significant similarities. The samples consist of water, protein, fat, organic acid, sugar, nitrogen compounds, and flavonoids.

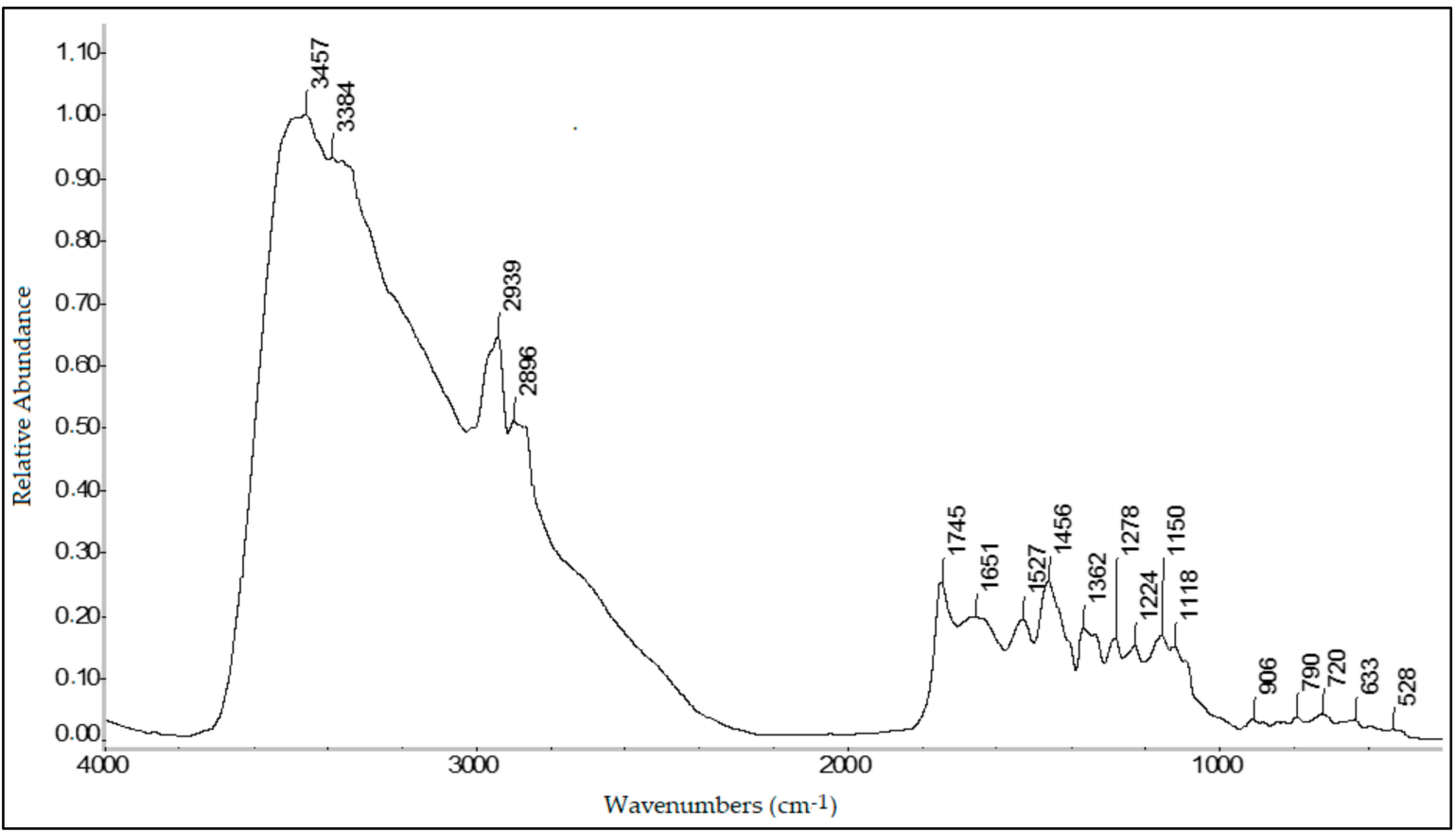

Figure 4. Mean FTIR spectrum derived from Robola sample.

Table 6. Main peaks of the FTIR spectrum derived from Robola sample.

\begin{tabular}{ccccc}
\hline Wavelengths $\mathbf{( c m}^{-\mathbf{1}} \mathbf{)}$ & Functional Group & Peak Performance & Assignment & Reference \\
\hline$\sim 3457$ & $\mathrm{O}-\mathrm{H}$ & Sugars & Stretching & Stretching \\
\hline$\sim 3384$ & $\mathrm{C}-\mathrm{N}$ & Proteins & [49] & [47] \\
\hline$\sim 2939$ & $\mathrm{C}-\mathrm{H}\left(-\mathrm{CH}_{2}\right)$ & Lipids & Symmetrical Stretching & {$[47,48]$} \\
\hline$\sim 2896$ & $\mathrm{C}-\mathrm{H}\left(-\mathrm{CH}_{2}\right)$ & Lipids & Asymmetric Stretching & {$[47,48]$} \\
\hline$\sim 1745$ & $\mathrm{C}=\mathrm{O} ;-\mathrm{COOR}$ & Pectins; Triglyceride ester linkages; & Stretching & {$[47,50]$} \\
\hline$\sim 1651$ & $\mathrm{C}=\mathrm{O} ;-\mathrm{COO}-$ & Amide I & Asymmetric Stretching & {$[50]$} \\
\hline$\sim 1527$ & $\mathrm{C}-\mathrm{N} ; \mathrm{N}-\mathrm{H}$ & Triglyceride ester linkages & Stretching, Bending & {$[47]$} \\
\hline$\sim 1456$ & $\mathrm{C}-\mathrm{N} ;-\mathrm{CH}{ }_{2}$ & Proteins; Amide II & Stretching, Bending & {$[47]$} \\
\hline
\end{tabular}


Table 6. Cont.

\begin{tabular}{ccccc}
\hline Wavelengths $\left.\mathbf{( c m}^{-\mathbf{1}}\right)$ & Functional Group & Peak Performance & Assignment & Reference \\
\hline$\sim 1362$ & $-\mathrm{CH}_{3}$ & Lipids & Symmetrical bending & [47] \\
\hline$\sim 1278$ & $\mathrm{C}-\mathrm{O}-\mathrm{C}$ & Lipids & Asymmetric Stretching & {$[47]$} \\
\hline$\sim 1150$ & $\mathrm{C}-\mathrm{O} ; \mathrm{C}-\mathrm{O}-\mathrm{C}$ & Polysaccharides; Coutin & Stretching & {$[49]$} \\
\hline$\sim 1118$ & $\mathrm{C}-\mathrm{O}-\mathrm{C}$ & Sugars; Polysaccharides & Stretching & {$[48]$} \\
\hline$\sim 790$ & $\mathrm{C}-\mathrm{C}$ & Lipids & Stretching & {$[49]$} \\
\hline$\sim 720$ & $-\mathrm{CH}_{2-}$ & Sugars & Swing & {$[49]$} \\
\hline$\sim 633$ & $\mathrm{C}-\mathrm{H}$ & Aromatic ring & Bending & {$[51,52]$} \\
\hline
\end{tabular}

Respectively, Raman spectra from grape skin extract are presented in Figure 5. The assignments of the major peaks are shown in Table 7. It was observed that the spectra showed significant similarities. The samples consisted of phenolic compounds distinguished in non-flavonoid phenols and flavonoid phenols. In particular, the extracts contained phenolic acids, flavonols, flavanones, tannins, and anthocyanins.

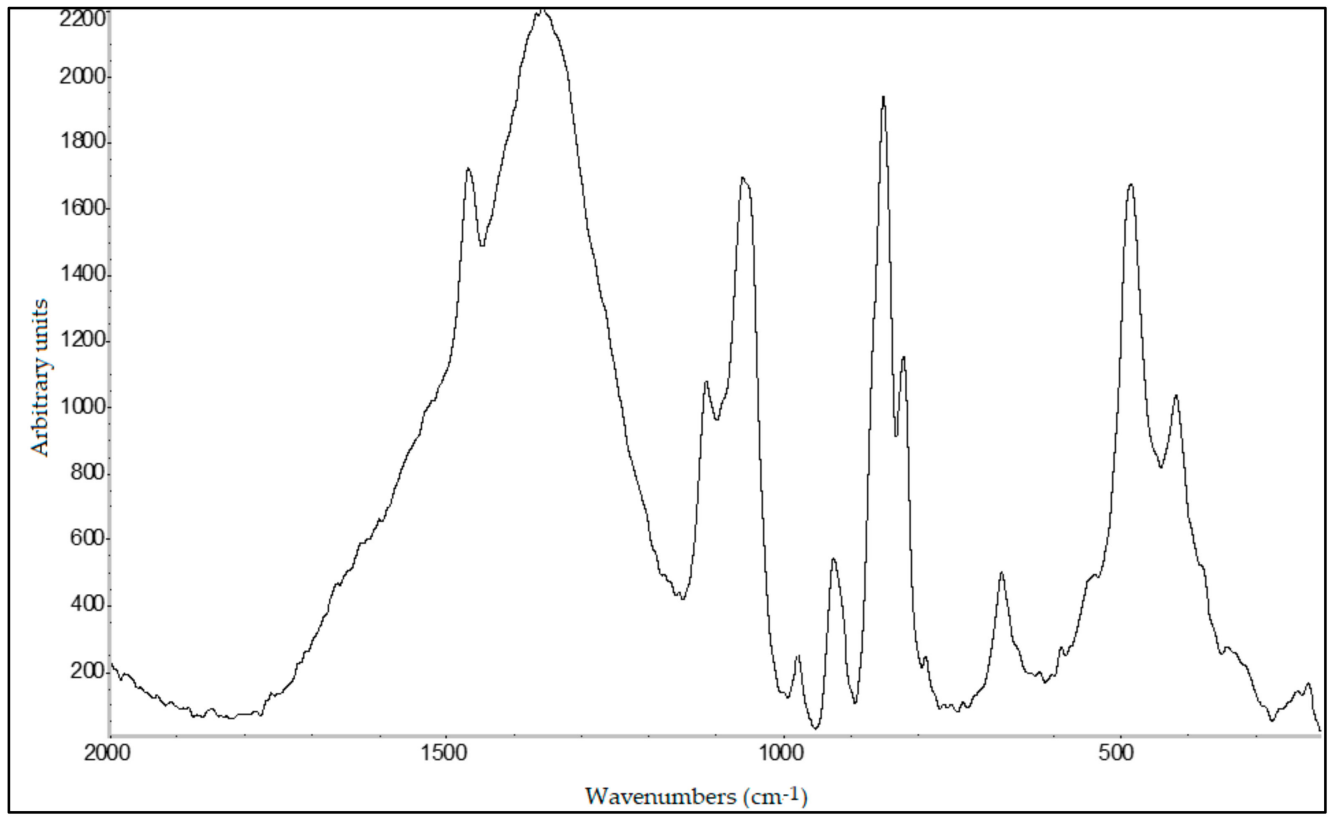

Figure 5. Mean Raman spectrum derived from Robola sample.

Table 7. Main peaks of the Raman spectrum derived from Robola sample.

\begin{tabular}{|c|c|c|c|c|}
\hline Wavelengths $\left(\mathrm{cm}^{-1}\right)$ & Functional Group & Peak Performance & Assignment & Reference \\
\hline$\sim 673$ & $\mathrm{C}=\mathrm{O}$ & Monosubstituted benzene & Deformation & {$[51,52]$} \\
\hline$\sim 786$ & $\mathrm{C}-\mathrm{C} ;-\mathrm{CH}_{2}$ & n-substituted benzene & Bending & [52] \\
\hline$\sim 819$ & $-\mathrm{CH}_{2}$ & n-substituted benzene & Bending & {$[52]$} \\
\hline$\sim 850$ & $\mathrm{C}-\mathrm{C}$ & Alkane & Bending & [51] \\
\hline$\sim 924$ & $\mathrm{C}-\mathrm{CH}_{3}$ & Alkanes off plane bending & Bending & {$[53,54]$} \\
\hline$\sim 975$ & $\mathrm{C}-\mathrm{CH}_{3}$ & Alkane & Bending & {$[54,55]$} \\
\hline$\sim 1058$ & Benzene & Disubstituted benzene derivatives & Bending & {$[53,54]$} \\
\hline$\sim 1112$ & $\mathrm{C}-\mathrm{C} ; \mathrm{C}-\mathrm{O}$ & Sugar & Bending & [53] \\
\hline$\sim 1364$ & $\mathrm{C}-\mathrm{H} ;-\mathrm{CH}_{3} ;-\mathrm{OH}$ & Alkanes, Phenols & Stretching & [48] \\
\hline
\end{tabular}


Table 7. Cont.

\begin{tabular}{ccccc}
\hline Wavelengths $\left.\mathbf{( c m}^{-\mathbf{1}}\right)$ & Functional Group & Peak Performance & Assignment & Reference \\
\hline$\sim 1466$ & $\mathrm{C}-\mathrm{H} ;-\mathrm{CH}_{3} ; \mathrm{C}=\mathrm{C}$ & Alkanes, Phenols & Stretching & [48] \\
\hline$\sim 1628$ & $\mathrm{C}=\mathrm{C}$ & Alkene, Aromatic ring & Bending & [48] \\
\hline$\sim 1849$ & $\mathrm{C}=\mathrm{O}$ & 5-membered cyclic anhydrides & Bending & {$[48]$} \\
\hline
\end{tabular}

\subsection{A Holistic Management of Winery by-Products Based on Their Chemical Analysis}

Chemical analysis of grape pomace showed that they consist of valuable phytochemicals like PUFAs, MUFAs, and polyphenols. These fatty acids can balance the PUFA/saturated fatty acid (SFA) ratio of the human diet [56]. Furthermore, studies have shown that a diet enriched in polyphenols has multiple benefits for human health such as cardiovascular and coronary heart diseases [57,58], diabetes [59], and anti-inflammatory activity $[60,61]$.

Foods enriched with grape pomace, either as extracts or as whole powder, have been demonstrated in the past. Cereals and dairy products would be able to be used for enrichment more easily [62-64]. Grape pomace has been successfully used in cheese manufacturing [65,66], marmalade or candies [67], salad dressing [68], and tomato puree [69]. Meat products are the food categories in which these by-products have been most widely used to prevent lipid oxidation. They have been applied in beef [70], pork [71,72], chicken [73], turkey [74], goat [75], and buffalo [76]. Grape seed oil was also proposed as an innovative food ingredient in various food formulations improving their nutritional properties [77]. The incorporation of grape seed oil (up to $10 \%$ ) was proposed to improve the fatty acid profile of frankfurters [78]. Otherwise, it can be used in cosmetics as it has moisturizing properties [79].

The availability of winery by-products in the Ionian Islands according to statistical data of the Greek Ministry of Agriculture is estimated in total at 1038.87 tons per year. Cephalonia Island contributes more than half (53\%) (Figure 6). Moreover, more details of mass balance are presented in Table 8 .

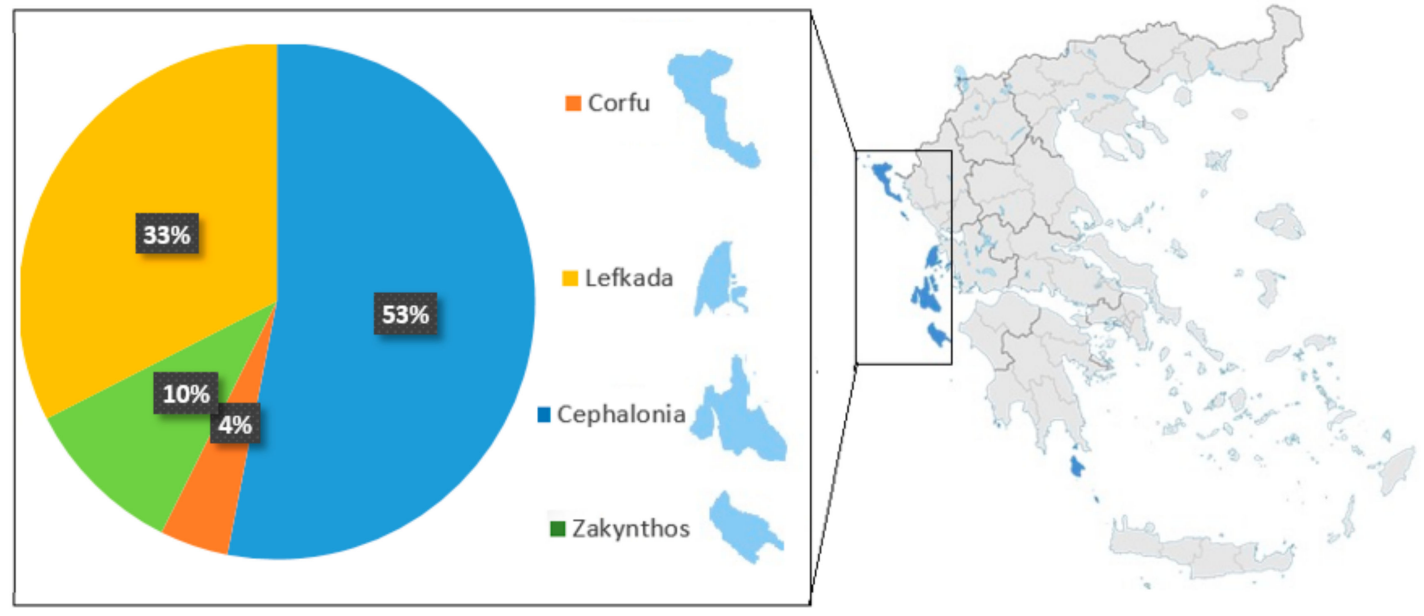

Figure 6. Spatial distribution of winery by-products in the Ionian Islands.

Based on estimated yields, a production of $5895.03 \mathrm{~L}$ per year of grape seed oil will provide a higher additive value. The minimized dry mass provides the advantages of easier and more cost-efficient transportation both inside the islands and especially to the mainland. In addition, their transport time will be much shorter without particularly high costs. The amount of 107.32 tons of grape seeds and skins can be reused as whole material in food or pharmaceutical companies contributing directly to the circular bioeconomy. 
These results also underline the importance of a management plan of by-products in the Ionian Islands.

Table 8. Mass balance of winery by-products from the Ionian Islands.

\begin{tabular}{|c|c|c|c|c|c|c|}
\hline Ionian Islands & Variety & $\begin{array}{c}\text { Annual } \\
\text { Production (tn) }\end{array}$ & $\begin{array}{l}\text { Grape Pomace } \\
(\text { tn })^{a}\end{array}$ & $\underset{a}{\text { Grape Seeds (tn) }}$ & $\underset{a}{\text { Grape Skins (tn) }}$ & $\begin{array}{c}\text { Grape Seeds Oil } \\
\text { Yield (L) }\end{array}$ \\
\hline \multirow{5}{*}{ Zakynthos } & Pavlos & $10.910 \pm 0.29$ & $1.091 \pm 0.03$ & $0.592 \pm 0.02$ & $0.499 \pm 0.01$ & $47.498 \pm 1.26$ \\
\hline & Avgoustiatis & $72.660 \pm 1.96$ & $6.771 \pm 0.18$ & $4.441 \pm 0.12$ & $2.331 \pm 0.06$ & $356.224 \pm 9.61$ \\
\hline & Robola & $5.030 \pm 0.03$ & $0.585 \pm 0.00$ & $0.339 \pm 0.00$ & $0.246 \pm 0.00$ & $27.209 \pm 0.16$ \\
\hline & Goustolidi & $10.865 \pm 0.35$ & $1.337 \pm 0.04$ & $0.426 \pm 0.01$ & $0.912 \pm 0.03$ & $34.141 \pm 1.10$ \\
\hline & Savvatiano & $5.750 \pm 0.10$ & $0.528 \pm 0.01$ & $0.187 \pm 0.00$ & $0.179 \pm 0.00$ & $14.968 \pm 0.26$ \\
\hline \multirow{3}{*}{ Corfu } & Robola & $22.220 \pm 0.09$ & $2.136 \pm 0.01$ & $0.624 \pm 0.00$ & $0.760 \pm 0.00$ & $50.045 \pm 0.20$ \\
\hline & Cabernet Sauvignon & $4.556 \pm 0.02$ & $0.370 \pm 0.00$ & $0.218 \pm 0.00$ & $0.152 \pm 0.00$ & $17.460 \pm 0.08$ \\
\hline & Kakotrygis & $17.794 \pm 0.28$ & $1.191 \pm 0.02$ & $0.733 \pm 0.01$ & $0.458 \pm 0.01$ & $58.833 \pm 0.93$ \\
\hline \multirow{5}{*}{ Cephalonia } & Sauvignon Blanc & $0.800 \pm 0.02$ & $0.119 \pm 0.00$ & $0.042 \pm 0.00$ & $0.077 \pm 0.00$ & $3.398 \pm 0.08$ \\
\hline & Tsaousi & $57.379 \pm 2.3$ & $6.539 \pm 0.26$ & $4.518 \pm 0.18$ & $2.022 \pm 0.08$ & $362.384 \pm 14.53$ \\
\hline & Robola & $393.573 \pm 1.6$ & $45.501 \pm 0.18$ & $33.846 \pm 0.14$ & $11.656 \pm 0.05$ & $2715.025 \pm 11.04$ \\
\hline & Goustolidi & $38.245 \pm 0.84$ & $3.392 \pm 0.07$ & $2.218 \pm 0.05$ & $1.174 \pm 0.03$ & $177.925 \pm 3.91$ \\
\hline & Mavrodaphne & $61.415 \pm 1.23$ & $5.747 \pm 0.12$ & $2.533 \pm 0.05$ & $1.992 \pm 0.04$ & $203.179 \pm 4.07$ \\
\hline \multirow{2}{*}{ Lefkada } & Vardea & $71.654 \pm 1.09$ & $6.445 \pm 0.10$ & $5.605 \pm 0.09$ & $0.840 \pm 0.01$ & $449.603 \pm 6.84$ \\
\hline & Vertzami & $266.014 \pm 3.2$ & $27.702 \pm 0.33$ & $17.168 \pm 0.21$ & $10.534 \pm 0.13$ & $1377.140 \pm 16.57$ \\
\hline
\end{tabular}

\section{Conclusions}

The present work outlined the importance of qualitative characteristics of winery by-products especially from traditional PDO grape varieties of Ionian Islands as a critical input to any by-product management plan towards a circular bioeconomy. To provide a realistic representation, by-product samples were collected directly from wineries after the vinification process. The solvents used were nontoxic and environmentally friendly. In addition, the application of green extraction processes ensures that the final products are safe for humans thus increasing the breadth of demand. Grape pomace can be used to empower business sectors of the food industry, beverage, medicine, cosmetics, cooking, feed, and many more. It can also be used as a whole material after a short preprocessing that involves moisture removal and pulverization. Furthermore, due to the ease and speed at which they can be transported, the same handling outcomes are inferred in lowering environmental and economic costs. All the above support the meaning of the circular economy, which states that anything previously classified as "by-products" can now be converted and classified as raw material. After a feasibility analysis, the qualitative data of winery by-products combined with annual production data by variety and per island, allowed for a first mass balance estimation that could form the basis of any management plan. In any case, further research into the optimization of each processing phase is needed to optimize efficiency.

Supplementary Materials: The following are available online at https:/ / www.mdpi.com/article/ 10.3390/su13105454/s1, Figure S1: A representative calibration curve of gallic acid. Figure S2: A representative calibration curve of DPPH inhibition by Trolox. Figure S3: A representative calibration curve of ABTS inhibition by Trolox.

Author Contributions: Conceptualization, M.X. and I.O.; methodology, C.S.P. and P.A.T.; software, M.X. and I.O; validation, I.K.L. and C.G.; formal analysis, C.K. and D.D.; investigation, M.X. and I.O.; data curation, C.K. and D.D.; writing-original draft preparation, M.X.; writing-review and editing, E.S.; supervision, E.S. and P.A.T.; project administration, E.S., C.S.P., and P.A.T. All authors have read and agreed to the published version of the manuscript. 
Funding: The present research was carried out by the Technological Educational Institution of the Ionian Islands within the framework of the project "Valorization of winemaking residues for the production of high added value raw materials for the food, cosmetics and parapharmaceutical industry" of the ROP "Ionia Nisia 2014-2020", co-funded by the European Union (ERDF) and Greece.

Institutional Review Board Statement: Not applicable.

Informed Consent Statement: Not applicable.

Data Availability Statement: Not applicable.

Acknowledgments: We thank Gentillini Winery, the Robola Cooperative of Cephalonia, Ktima Grampsa, and Ktima Theotoki Wineries for winery by-products samples.

Conflicts of Interest: The authors declare no conflict of interest.

\section{References}

1. Food and Agricultural Organization. FAOSTAT. Available online: http:/ / www.fao.org/faostat/en/ (accessed on 20 March 2021).

2. International Organisation of Vine and Wine. OIV. 2016. Available online: http://www.oiv.int/ (accessed on 20 March 2021).

3. Ministry of Rural Development and Food. 2018. Available online: http://www.minagric.gr/index.php/el/ (accessed on 20 March 2021).

4. Teixeira, A.; Baenas, N.; Dominguez-Perles, R.; Barros, A.; Rosa, E.; Moreno, D.A.; Garcia-Viguera, C. Natural Bioactive Compounds from Winery By-Products as Health Promoters: A Review. Int. J. Mol. Sci. 2014, 15, 15638-15678. [CrossRef] [PubMed]

5. Da Silva, A.C.; Jorge, N. Bioactive compounds of oils extracted from fruits seeds obtained from agroindustrial waste. Eur. J. Lipid Sci. Technol. 2017, 119, 1600024. [CrossRef]

6. Devesa-Rey, R.; Vecino, X.; Varela-Alende, J.; Barral, M.; Cruz, J.; Moldes, A. Valorization of winery waste vs. the costs of not recycling. Waste Manag. 2011, 31, 2327-2335. [CrossRef]

7. Moletta, R. Winery and distillery wastewater treatment by anaerobic digestion. Water Sci. Technol. 2005, 51, 137-144. [CrossRef] [PubMed]

8. Maier, T.; Schieber, A.; Kammerer, D.R.; Carle, R. Residues of grape (Vitis vinifera L.) seed oil production as a valuable source of phenolic antioxidants. Food Chem. 2009, 112, 551-559. [CrossRef]

9. Beveridge, T.H.J.; Girard, B.; Kopp, A.T.; Drover, J.C.G. Yield and Composition of Grape Seed Oils Extracted by Supercritical Carbon Dioxide and Petroleum Ether: Varietal Effects. J. Agric. Food Chem. 2005, 53, 1799-1804. [CrossRef]

10. Sabir, A.; Unver, A.; Kara, Z. The fatty acid and tocopherol constituents of the seed oil extracted from 21 grape varieties (Vitis spp.). J. Sci. Food Agric. 2012, 92, 1982-1987. [CrossRef] [PubMed]

11. Arvanitoyannis, I.S.; Ladas, D.; Mavromatis, A. Potential uses and applications of treated wine waste: A review. Int. J. Food Sci. Technol. 2006, 41, 475-487. [CrossRef]

12. Lafka, T.I.; Sinanoglou, V.; Lazos, E.S. On the extraction and antioxidant activity of phenolic compounds from winery wastes. Food Chem. 2007, 104, 1206-1214. [CrossRef]

13. Babbar, N.; Oberoi, H.S.; Sandhu, S.K. Therapeutic and Nutraceutical Potential of Bioactive Compounds Extracted from Fruit Residues. Crit. Rev. Food Sci. Nutr. 2014, 55, 319-337. [CrossRef]

14. Philippi, K.; Tsamandouras, N.; Grigorakis, S.; Makris, D.P. Ultrasound-Assisted Green Extraction of Eggplant Peel (Solanum melongena) Polyphenols Using Aqueous Mixtures of Glycerol and Ethanol: Optimisation and Kinetics. Environ. Process. 2016, 3, 369-386. [CrossRef]

15. Apostolakis, A.; Grigorakis, S.; Makris, D.P. Optimisation and comparative kinetics study of polyphenol extraction from olive leaves (Olea europaea) using heated water/glycerol mixtures. Sep. Purif. Technol. 2014, 128, 89-95. [CrossRef]

16. Karakashov, B.; Grigorakis, S.; Loupassaki, S.; Makris, D.P. Optimisation of polyphenol extraction from Hypericum perforatum (St. John's Wort) using aqueous glycerol and response surface methodology. J. Appl. Res. Med. Aromat. Plants 2015, 2, 1-8. [CrossRef]

17. Fernandes, L.; Casal, S.; Cruz, R.; Pereira, J.A.; Ramalhosa, E. Seed oils of ten traditional Portuguese grape varieties with interesting chemical and antioxidant properties. Food Res. Int. 2013, 50, 161-166. [CrossRef]

18. Zhao, L.; Yagiz, Y.; Xu, C.; Lu, J.; Chung, S.; Marshall, M.R. Muscadine grape seed oil as a novel source of tocotrienols to reduce adipogenesis and adipocyte inflammation. Food Funct. 2015, 6, 2293-2302. [CrossRef]

19. Davidov-Pardo, G.; McClements, D.J. Nutraceutical delivery systems: Resveratrol encapsulation in grape seed oil nanoemulsions formed by spontaneous emulsification. Food Chem. 2015, 167, 205-212. [CrossRef]

20. Singleton, V.L.; Orthofer, R.; Lamuela-Raventos, R.M. Section III. Polyphenols and Flavonoids-14-Analysis of Total Phenols and Other Oxidation Substrates and Antioxidants by Means of Folin-Ciocalteu reagent. Meth. Enzymol. 1999, 299, 152-177. [CrossRef]

21. Singh, R.P.; Murthy, C.K.N.; Jayaprakasha, G.K. Studies on the antioxidant activity of pomegranate (Punica granatum) peel and seed extracts using in vitro models. J. Agric. Food Chem. 2002, 50, 81-86. [CrossRef] [PubMed] 
22. Magalhaes, L.; Segundo, M.A.; Reis, S.; Lima, J.L. Methodological aspects about in vitro evaluation of antioxidant properties. Anal. Chim. Acta 2008, 613,1-19. [CrossRef]

23. Kallithraka, S.; Mohdaly, A.A.-A.; Makris, D.P.; Kefalas, P. Determination of major anthocyanin pigments in Hellenic native grape varieties (Vitis vinifera sp.): Association with antiradical activity. J. Food Compos. Anal. 2005, 18, 375-386. [CrossRef]

24. Makris, D.P.; Kefalas, P. Characterization of Polyphenolic Phytochemicals in Red Grape Pomace. Int. J. Waste Resour. 2013, 3. [CrossRef]

25. Cheng, V.J.; Bekhit, A.E.D.A.; McConnell, M.; Mros, S.; Zhao, J. Effect of extraction solvent, waste fraction and grape variety on the antimicrobial and antioxidant activities of extracts from wine residue from cool climate. Food Chem. 2012, 134, 474-482. [CrossRef]

26. Fernandez-Martinez, J.; Del Rio, M.; De Haro, A. Survey of safflower (Carthamus tinctorius L.) germplasm for variants in fatty acid composition and other seed characters. Euphytica 1993, 69, 115-122. [CrossRef]

27. Yang, R.; Zhang, L.; Li, P.; Yu, L.; Mao, J.; Wang, X.; Zhang, Q. A review of chemical composition and nutritional properties of minor vegetable oils in China. Trends Food Sci. Technol. 2018, 74, 26-32. [CrossRef]

28. Lutterodt, H.; Slavin, M.; Whent, M.; Turner, E.; Yu, L. (Lucy) Fatty acid composition, oxidative stability, antioxidant and antiproliferative properties of selected cold-pressed grape seed oils and flours. Food Chem. 2011, 128, 391-399. [CrossRef]

29. Matthäus, B. Virgin grape seed oil: Is it really a nutritional highlight? Eur. J. Lipid Sci. Technol. 2008, 110, 645-650. [CrossRef]

30. Fiori, L.; De Faveri, D.; Casazza, A.A.; Perego, P. Grape by-products: Extraction of polyphenolic compounds using supercritical $\mathrm{CO}_{2}$ and liquid organic solvent: A preliminary investigation Subproductos de la uva: Extracción de compuestos polifenólicos usando $\mathrm{CO}_{2}$ supercrítico y disolventes orgánicos líquidos—una investigación preliminar. CyTA J. Food 2009, 7, 163-171. [CrossRef]

31. Ben Mohamed, H.; Duba, K.S.; Fiori, L.; Abdelgawed, H.; Tlili, I.; Tounekti, T.; Zrig, A. Bioactive compounds and antioxidant activities of different grape (Vitis vinifera L.) seed oils extracted by supercritical $\mathrm{CO}_{2}$ and organic solvent. LWT 2016, 74, 557-562. [CrossRef]

32. Antolovich, M.; Prenzler, P.D.; Patsalides, E.; McDonald, S.; Robards, K. Methods for testing antioxidant activity. Analyst 2002, 127, 183-198. [CrossRef]

33. European Commission. Characteristics of olive and olive pomace oils and their analytical methods. Regulation EC/1989/2003. Off. J. Eur Comm. 2003, L295, 57-66.

34. Czamara, K.; Majzner, K.; Pacia, M.Z.; Kochan, K.; Kaczor, A.; Baranska, M. Raman spectroscopy of lipids: A review. J. Raman Spectrosc. 2015, 46, 4-20. [CrossRef]

35. Beattie, J.R.; Bell, S.E.J.; Borgaard, C.; Fearon, A.; Moss, B.W. Prediction of adipose tissue composition using raman spectroscopy: Average properties and individual fatty acids. Lipids 2006, 41, 287-294. [CrossRef]

36. Di Lecce, G.; Arranz, S.; Jáuregui, O.; Tresserra-Rimbau, A.; Quifer-Rada, P.; Lamuela-Raventós, R.M. Phenolic profiling of the skin, pulp and seeds of Albariño grapes using hybrid quadrupole time-of-flight and triple-quadrupole mass spectrometry. Food Chem. 2014, 145, 874-882. [CrossRef] [PubMed]

37. Bonilla, F.; Mayen, M.; Merida, J.; Medina, M. Extraction of phenolic compounds from red grape marc for use as food lipid antioxidants. Food Chem. 1999, 66, 209-215. [CrossRef]

38. Mattivi, F.; Guzzon, R.; Vrhovsek, U.; Stefanini, A.M.; Velasco, R. Metabolite Profiling of Grape: Flavonols and Anthocyanins. J. Agric. Food Chem. 2006, 54, 7692-7702. [CrossRef]

39. Jeffery, D.; Parker, M.; Smith, P. Flavonol composition of Australian red and white wines determined by high-performance liquid chromatography. Aust. J. Grape Wine Res. 2008, 14, 153-161. [CrossRef]

40. González-Centeno, M.R.; Jourdes, M.; Femenia, A.; Simal, S.; Rosselló, C.; Teissedre, P.-L. Proanthocyanidin Composition and Antioxidant Potential of the Stem Winemaking Byproducts from 10 Different Grape Varieties (Vitis vinifera L.). J. Agric. Food Chem. 2012, 60, 11850-11858. [CrossRef] [PubMed]

41. Ky, I.; Lorrain, B.; Kolbas, N.; Crozier, A.; Teissedre, P.-L. Wine by-Products: Phenolic Characterization and Antioxidant Activity Evaluation of Grapes and Grape Pomaces from Six Different French Grape Varieties. Molecules 2014, 19, 482-506. [CrossRef]

42. Bosso, A.; Cassino, C.; Motta, S.; Panero, L.; Tsolakis, C.; Guaita, M. Polyphenolic Composition and In Vitro Antioxidant Activity of Red Grape Seeds as Byproducts of Short and Medium-Long Fermentative Macerations. Foods 2020, 9, 1451. [CrossRef]

43. Guaita, M.; Panero, L.; Motta, S.; Mangione, B.; Bosso, A. Effects of high-temperature drying on the polyphenolic composition of skins and seeds from red grape pomace. LWT 2021, 145, 111323. [CrossRef]

44. Bosso, A.; Guaita, M.; Petrozziello, M. Influence of solvents on the composition of condensed tannins in grape pomace seed extracts. Food Chem. 2016, 207, 162-169. [CrossRef] [PubMed]

45. Guaita, M.; Bosso, A. Polyphenolic Characterization of Grape Skins and Seeds of Four Italian Red Cultivars at Harvest and after Fermentative Maceration. Foods 2019, 8, 395. [CrossRef]

46. Motta, S.; Guaita, M.; Cassino, C.; Bosso, A. Relationship between polyphenolic content, antioxidant properties and oxygen consumption rate of different tannins in a model wine solution. Food Chem. 2020, 313, 126045. [CrossRef]

47. Karoui, R.; Downey, G.; Blecker, C. Mid-Infrared Spectroscopy Coupled with Chemometrics: A Tool for the Analysis of Intact Food Systems and the Exploration of Their Molecular Structure: Quality Relationships-A Review. Chem. Rev. 2010, 110, 6144-6168. [CrossRef] [PubMed]

48. Nogales-Bueno, J.; Baca-Bocanegra, B.; Rooney, A.; Hernández-Hierro, J.M.; Heredia, F.J.; Byrne, H.J. Linking ATR-FTIR and Raman features to phenolic extractability and other attributes in grape skin. Talanta 2017, 167, 44-50. [CrossRef] [PubMed] 
49. Heredia-Guerrero, J.A.; Benãtez, J.; Domãnguez, E.; Bayer, I.S.; Ecingolani, R.; Eathanassiou, A.; Eheredia, A. Infrared and Raman spectroscopic features of plant cuticles: A review. Front. Plant Sci. 2014, 5, 305. [CrossRef] [PubMed]

50. Hanlin, R.; Hrmová, M.; Harbertson, J.; Downey, M. Review: Condensed tannin and grape cell wall interactions and their impact on tannin extractability into wine. Aust. J. Grape Wine Res. 2010, 16, 173-188. [CrossRef]

51. Bancuta, O.R.; Chilian, A.; Bancuta, I.; Ion, R.M.; Setnescu, R.; Setnescu, T.; Gheboianu, A.; Lungulescu, M. FT-IR and UV-VIS Characterization of grape extracts used as antioxidants in polymers. Rev. Roum. Chim. 2015, 60, 571-577.

52. Fernández, K.; Agosin, E. Quantitative Analysis of Red Wine Tannins Using Fourier-Transform Mid-Infrared Spectrometry. J. Agric. Food Chem. 2007, 55, 7294-7300. [CrossRef]

53. Ping, L.; Pizzi, A.; Guo, Z.D.; Brosse, N. Condensed tannins from grape pomace: Characterization by FTIR and MALDI TOF and production of environment friendly wood adhesive. Ind. Crop. Prod. 2012, 40, 13-20. [CrossRef]

54. Boulet, J.; Williams, P.; Doco, T. A Fourier transform infrared spectroscopy study of wine polysaccharides. Carbohydr. Polym. 2007, 69, 79-85. [CrossRef]

55. Kacuráková, M. FT-IR study of plant cell wall model compounds: Pectic polysaccharides and hemicelluloses. Carbohydr. Polym. 2000, 43, 195-203. [CrossRef]

56. Williams, C.M. Dietary fatty acids and human health. Anim. Res. 2000, 49, 165-180. [CrossRef]

57. Khurana, S.; Venkataraman, K.; Hollingsworth, A.; Piche, M.; Tai, T.C. Polyphenols: Benefits to the Cardiovascular System in Health and in Aging. Nutrients 2013, 5, 3779-3827. [CrossRef]

58. Quiñones, M.; Miguel, M.; Aleixandre, A. Beneficial effects of polyphenols on cardiovascular disease. Pharmacol. Res. 2013, 68, 125-131. [CrossRef]

59. Bahadoran, Z.; Mirmiran, P.; Azizi, F. Dietary polyphenols as potential nutraceuticals in management of diabetes: A review. J. Diabetes Metab. Disord. 2013, 12, 43. [CrossRef] [PubMed]

60. Kim, S.K.; Kim, H.; Kim, S.A.; Park, H.K.; Kim, W. Anti-Inflammatory and Anti-Superbacterial Activity of Polyphenols Isolated from Black Raspberry. Korean J. Physiol. Pharmacol. 2013, 17, 73-79. [CrossRef]

61. Nichols, J.A.; Katiyar, S.K. Skin photoprotection by natural polyphenols: Anti-inflammatory, antioxidant and DNA repair mechanisms. Arch. Dermatol. Res. 2009, 302, 71-83. [CrossRef] [PubMed]

62. Jr, C.H.; Ross, C.F. Total Phenolic Content, Consumer Acceptance, and Instrumental Analysis of Bread Made with Grape Seed Flour. J. Food Sci. 2011, 76, S428-S436. [CrossRef]

63. Florina, M.M.; Ramona, G.; Ersilia, A.; Mariana, P.A.; Melinda, O. Determination of the nutritional properties from grape seed flour. Curr. Opin. Biotechnol. 2013, 24, S115. [CrossRef]

64. Chouchouli, V.; Kalogeropoulos, N.; Konteles, S.J.; Karvela, E.; Makris, D.P.; Karathanos, V.T. Fortification of yoghurts with grape (Vitis vinifera) seed extracts. LWT 2013, 53, 522-529. [CrossRef]

65. Han, J.; Britten, M.; St-Gelais, D.; Champagne, C.P.; Fustier, P.; Salmieri, S.; Lacroix, M. Polyphenolic compounds as functional ingredients in cheese. Food Chem. 2011, 124, 1589-1594. [CrossRef]

66. Marchiani, R.; Bertolino, M.; Belviso, S.; Giordano, M.; Ghirardello, D.; Torri, L.; Piochi, M.; Zeppa, G. Yogurt Enrichment with Grape Pomace: Effect of Grape Cultivar on Physicochemical, Microbiological and Sensory Properties. J. Food Qual. 2016, 39, 77-89. [CrossRef]

67. Cappa, C.; Lavelli, V.; Mariotti, M. Fruit candies enriched with grape skin powders: Physicochemical properties. LWT 2015, 62, 569-575. [CrossRef]

68. Tseng, A.; Zhao, Y. Wine grape pomace as antioxidant dietary fibre for enhancing nutritional value and improving storability of yogurt and salad dressing. Food Chem. 2013, 138, 356-365. [CrossRef]

69. Lavelli, V.; Harsha, P.S.; Torri, L.; Zeppa, G. Use of winemaking by-products as an ingredient for tomato puree: The effect of particle size on product quality. Food Chem. 2014, 152, 162-168. [CrossRef] [PubMed]

70. Ahn, J.; Grün, I.U.; Mustapha, A. Effects of plant extracts on microbial growth, color change, and lipid oxidation in cooked beef. Food Microbiol. 2007, 24, 7-14. [CrossRef]

71. Carpenter, R.; O'Grady, M.; O'Callaghan, Y.; O’Brien, N.; Kerry, J. Evaluation of the antioxidant potential of grape seed and bearberry extracts in raw and cooked pork. Meat Sci. 2007, 76, 604-610. [CrossRef]

72. Sasse, A.; Colindres, P.; Brewer, M.S. Effect of Natural and Synthetic Antioxidants on the Oxidative Stability of Cooked, Frozen Pork Patties. J. Food Sci. 2009, 74, S30-S35. [CrossRef]

73. Shirahigue, L.D.; Contreras-Castillo, C.J.; Selani, M.M.; Nadai, A.P.; Mourão, G.B.; Gallo, C.R. Winery grape-residue extract: Effects on quality and sensory attributes of cooked chicken meat. Food Sci. Biotechnol. 2011, 20, 1257-1264. [CrossRef]

74. Mielnik, M.; Olsen, E.; Vogt, G.; Adeline, D.; Skrede, G. Grape seed extract as antioxidant in cooked, cold stored turkey meat. LWT 2006, 39, 191-198. [CrossRef]

75. Rababah, T.M.; Feng, H.; Yang, W.; Al-Mahasneh, M.; Ereifej, K.; Al-U’Datt, M. Effect of grape seed extracts on physico-chemical and sensory properties of goat meat cooked by conventional electric or microwave ovens. Food Sci. Technol. Res. 2012, 18, 325-332. [CrossRef]

76. Tajik, H.; Aminzare, M.; Raad, T.M.; Hashemi, M.; Azar, H.H.; Raeisi, M.; Naghili, H. Effect of Z ataria multiflora Boiss Essential Oil and Grape Seed Extract on the Shelf Life of Raw Buffalo Patty and Fate of Inoculated L isteria monocytogenes. J. Food Process. Preserv. 2015, 39, 3005-3013. [CrossRef] 
77. Jung, Y.K.; Jung, S.; Lee, H.J.; Kang, M.G.; Lee, S.K.; Kim, Y.J.; Jo, C. Effect of High Pressure after the Addition of Vegetable Oil on the Safety and Quality of Beef Loin. Food Sci. Anim. Resour. 2012, 32, 68-76. [CrossRef]

78. Da Porto, C.; Porretto, E.; Decorti, D. Comparison of ultrasound-assisted extraction with conventional extraction methods of oil and polyphenols from grape (Vitis vinifera L.) seeds. Ultrason. Sonochemistry 2013, 20, 1076-1080. [CrossRef]

79. Sotiropoulou, E.I.; Varelas, V.; Liouni, M.; Nerantzis, E.T. Grape Seed Oil: From a Winery Waste to a Value Added Cosmetic Product-a Review. 2015. Available online: https:/ /www.researchgate.net/publication/ (accessed on 20 April 2020). 